Review

\title{
Pathophysiology of GPCR Homo- and Heterodimerization: Special Emphasis on Somatostatin Receptors
}

\section{Rishi K. Somvanshi and Ujendra Kumar *}

Faculty of Pharmaceutical Sciences, Division of Pharmacology and Toxicology, The University of British Columbia, Vancouver, BC, V6T 1Z3, Canada

* Author to whom correspondence should be addressed; E-Mail: ujkumar@mail.ubc.ca; Tel.: +1-604-827-3660; Fax: +1-604-822-3035.

Received: 3 February 2012; in revised form: 18 April 2012 / Accepted: 19 April 2012 /

Published: 27 April 2012

\begin{abstract}
G-protein coupled receptors (GPCRs) are cell surface proteins responsible for translating $>80 \%$ of extracellular reception to intracellular signals. The extracellular information in the form of neurotransmitters, peptides, ions, odorants etc is converted to intracellular signals via a wide variety of effector molecules activating distinct downstream signaling pathways. All GPCRs share common structural features including an extracellular $N$-terminal, seven-transmembrane domains (TMs) linked by extracellular/intracellular loops and the $C$-terminal tail. Recent studies have shown that most GPCRs function as dimers (homo- and/or heterodimers) or even higher order of oligomers. Protein-protein interaction among GPCRs and other receptor proteins play a critical role in the modulation of receptor pharmacology and functions. Although $\sim 50 \%$ of the current drugs available in the market target GPCRs, still many GPCRs remain unexplored as potential therapeutic targets, opening immense possibility to discover the role of GPCRs in pathophysiological conditions. This review explores the existing information and future possibilities of GPCRs as tools in clinical pharmacology and is specifically focused for the role of somatostatin receptors (SSTRs) in pathophysiology of diseases and as the potential candidate for drug discovery.
\end{abstract}

Keywords: somatostatin; somatostatin receptors; heterodimerization; G proteins; GPCRs; Pb-FRET 


\section{Abbreviations}

AR, adrenoceptor; cAMP, cyclic adenosine monophosphate; AT1R, Angiotensin receptor 1; Ang II, angiotensin II; CNS, Central nervous system; $C$-tail, Carboxyl Terminal Tail; CXCR, Chemokine receptor; CO-IP, Co-immunoprecipitation; DR, Dopamine Receptor; ECL, Extracellular loop; EP1, prostaglandin E1 receptor; ER, Endoplasmic reticulum; ERKs, extracellular signal-regulated kinases; EGFR, Epidermal growth factor receptor; FSHR, Follicle-stimulating hormone receptor; FSK, forskolin; GABAR, gamma-aminobutyric acid receptor; GPCRs, G-protein coupled receptors; GRK, GPCR kinases; hSSTR, human somatostatin receptor; HA, hemagglutinin; HEK-293, human embryonic kidney-293; ICL, Intracellular loop; MAPK, mitogen-activated protein kinase; MR, muscarinic receptor; NMDAR, $N$-Methyl-D-aspartate receptor; ORs, Opioid Receptors; Pb-FRET, Photobleaching-fluorescence resonance energy transfer; PKC, Protein kinase C; PTX, pertussis toxin; RTK, Receptor tyrosine kinase; SSTRs, somatostatin receptors; TRs, Taste Receptors, V2R, Vasopressin receptor 2, 5-HT, Serotonin Receptor; CaSR, Calcium Sensing receptor; FCS, Fluorescence correlation spectroscopy; PD, Parkinson's Disease.

\section{Introduction}

G-protein coupled receptors (GPCRs) are the most prominent cell membrane receptor proteins which function in conjunction with second messengers and are involved in the regulation of many downstream signaling pathways. Several pathological conditions have been associated with the abnormal function or imbalance in GPCRs expression and have drawn great attention of pharmaceutical industries as an initiative to develop new drugs targeting several diseases like cancer, neurodegeneration, diabetes, pain and inflammation. It is therefore not surprising that some $50 \%$ of drugs currently on the market are associated with GPCRs and account for $>40$ billion USD annual revenue [1]. As early as 1993, Attwood and Findlay made an unique effort to classify GPCRs on the basis of the sequence of seven hydrophobic domains [2]. In 1994, Kolakowski presented the A-F classification system for all receptors which bind to G-proteins and the remaining were assigned to the O (other) family [3]. Bockaert and Pin in 1999 used structural and ligand binding criteria to segregate GPCRs into family 1-5 [4]. The most comprehensive classification of GPCRs was accomplished on the basis of phylogenetic criteria by Fredriksson and colleagues [5,6]. Today, $>800$ GPCRs exist in the human genome and have been classified in five distinct families. Amongst all classes of GPCRs, the rhodopsin family is the largest and most studied, accounting for more than 650 receptor types, whereas the remaining four classes of GPCRs have relatively less number of receptors, ranging from 15-36 [7].

The functional entity of GPCRs has been controversial and it was believed that the majority of GPCRs at cell surface exists and functions as monomers. However, in last ten years significant progress has been made and now it is widely accepted that most if not all GPCRs function as homodimers and/or heterodimers within the family or with members of other receptor families. The process of receptors dimerization can occur as early as during protein synthesis and its sorting at the level of endoplasmic reticulum (ER) [8,9]. As described earlier, vasopressin, oxytocin and calcium sensing receptors (CaSR) exist as dimers in the ER [10,11]. With the recent advances in methodology to ascertain protein-protein interactions, it has become clear that dimerization is not a unique property 
of GPCRs and it has also been expanded to many other receptor subtypes, including ligand gated channels such as $N$-Methyl-D-aspartate receptors (NMDARs) and the members of the receptor tyrosine kinase family $[12,13]$. Members of the receptor tyrosine kinase family such as epidermal growth factor receptors (EGFRs), commonly known as ErbBs, have been studied extensively for homo- and/or heterodimerization with significant pathological importance, specifically in different type of tumors [14]. EGFR in basal state exist as monomers at the cell surface and exhibit homo- and/or heterodimerization in the presence of ligands or even in case of over-expression. Recent studies have shown that EGFR heterodimerization is not restricted within the family, but also constitute a receptor complex with the members of GPCR family, such as somatostatin receptors (SSTRs) [15-17].

To study receptor dimerization different methods have been employed, including classical methods such as co-immunoprecipitation (Co-IP) to advance fluorescence based biophysical techniques, which exploit epitope tags of the receptors when expressed in heterologous system [18] (Table 1). As many GPCRs are expressed endogenously, HEK-293, CHO-k1 and COS cells have been instrumental for the characterization of GPCRs [19]. The use of recombinant DNA expression systems has proved to be an influential tool for this objective as various chimeric and mutant GPCRs are constructed [20]. These chimeric molecules were used recently to delineate the functional properties of the receptors in heterologous systems. Like for complementation assay, signaling deficient SSTR5 when expressed with binding deficient SSTR5, restoration of receptor signaling and functionality was observed [21]. Similarly, two non-functional GPCR chimeras, one with first five transmembrane domains (TMs) of the $\alpha_{2}$-adrenoceptor $\left(\alpha_{2} \mathrm{AR}\right)$ and last two TMs of muscarinic receptor 3 or vice versa, displayed restoration of receptor functionality [22]. Similar results were also demonstrated for the angiotensin 2 receptor, luteinzing hormone and vasopressin receptors (V2R) [23-27]. Most convincing evidence for the functional significance of GPCRs was shown for $\beta$-adrenoceptors ( $\beta$-ARs), as a peptide mimicking TM VI of the $\beta_{2} \mathrm{AR}$ resulted in the blockade of dimerization and agonist induced signaling [28]. These observations have served as a platform to delineate the structure and function studies and further characterization of many other GPCRs [28]. The modulation of pharmacological properties including binding properties, receptor trafficking and signaling of receptors upon dimerization has been observed in many studies involving opioid receptors (ORs), ARs, SSTRs and Dopamine Receptors (DRs). The existence of monomeric and oligomeric receptors on the cell surface has always been a point of debate. Many of the drugs targeting GPCRs were based on the monomeric form of the receptors however, the ratio of proportional distribution of monomeric/homodimeric/heterodimeric forms of the receptors existing on the cell surface is largely elusive [29].

SSTR subtypes are members of the GPCRs super family and belong to Class A Rhodopsin type subgroup. Many studies emerging from authors' lab and elsewhere have demonstrated SSTR subtypes ability to form both homo- and/or heterodimers with members of the same or distantly related receptor subtypes [15,16,21,30-40]. In the present review, we highlight the functional significance of G-proteins and key receptor structural motifs which are responsible for receptor signaling and dimerization. However, this review is focused around the member of Class A GPCR namely SSTR subtypes and their interaction with DRs, ORs and ARs as well as RTKs. Furthermore, we also discuss the functional significance of this interaction with possible clinical implication in the process of drug discovery. 
Table 1. The list of techniques used to determine homo- and/or heterodimerization.

\begin{tabular}{|c|c|c|}
\hline Method & Receptors & References \\
\hline Complementation Assay & $\begin{array}{l}\text { Somatostatin receptors } 1,4 \text { and } 5 \\
\text { Calcium sensing receptor } \\
\text { Muscarinic } \mathrm{M} 2 \text { and } \mathrm{M} 3 \text { receptors } \\
\text { Muscarinic } \mathrm{M} 3 / \alpha 2 \text { Adrenoceptor } \\
\text { Dopamine receptor } 2 / 3 \\
\mathrm{GABAR}_{1} / \mathrm{GABAR}_{2}\end{array}$ & $\begin{array}{l}{[21,36]} \\
{[41]} \\
{[42]} \\
{[22]} \\
{[43]} \\
{[44]}\end{array}$ \\
\hline Co-Immunoprecipitation & 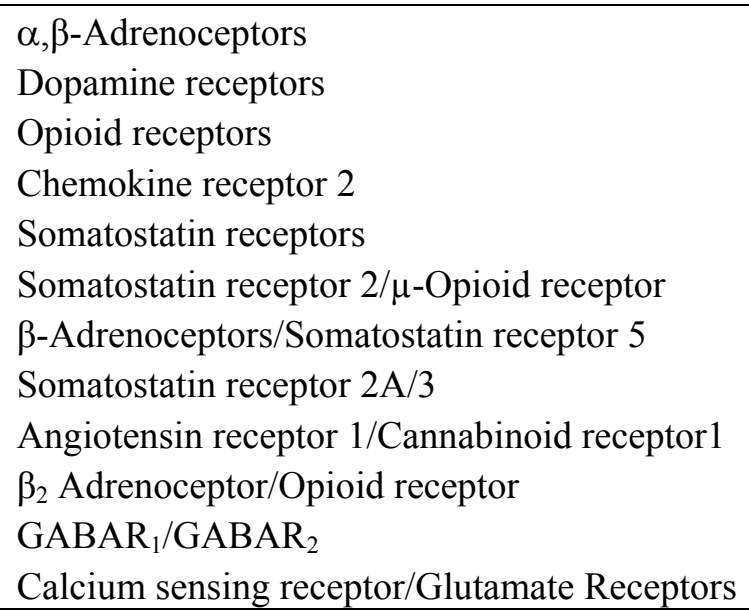 & $\begin{array}{l}{[45,46]} \\
{[47,48]} \\
{[49,50]} \\
{[51]} \\
{[31,32,34-36,52]} \\
{[53]} \\
{[37,40]} \\
{[52]} \\
{[54]} \\
{[55]} \\
{[56,57]} \\
{[58]}\end{array}$ \\
\hline FRET & $\begin{array}{l}\alpha \text {-Adrenoceptors } \\
\text { Thyrotropin receptor } \\
\text { Neuropeptide Y receptor } \\
\text { Dopamine receptor } 2 \\
\text { Chemokine receptor } 2 \text { and } 5 \\
\text { Somatostatin Receptors }\end{array}$ & $\begin{array}{l}{[45]} \\
{[59]} \\
{[60]} \\
{[61]} \\
{[62]} \\
{[63,64]}\end{array}$ \\
\hline Photobleaching-FRET & $\begin{array}{l}\text { Somatostatin receptors } \\
\text { Gonadotrophin-releasing hormone receptors } \\
\text { Somatostatin receptors/Dopamine receptor } \\
\text { Somatostatin receptor } 5 / \beta \text {-Adrenoceptors } \\
\text { Somatostatin receptor } 4 / \mu \text {-Opioid receptor } \\
\text { Somatostatin receptor } 4 / \delta \text {-Opioid receptor } \\
\text { Somatostatin receptors/EGFRs }\end{array}$ & $\begin{array}{l}{[21,31,32,34,36,38]} \\
{[65,66]} \\
{[30,35]} \\
{[37,40]} \\
{[67]} \\
{[39]} \\
{[15-17]}\end{array}$ \\
\hline BRET & $\begin{array}{l}\beta \text {-Adrenoceptors } \\
\text { Thyrotropin-releasing hormone receptor } \\
\text { Opioid receptors } \\
\text { Chemokine receptor } 4 \text { and } 5 \\
\text { Adenosine receptor } \\
\text { Oxytocin Receptor } \\
\text { Vasopressin Receptor } \\
\text { Adenosine } 2 \text { a receptor/Dopamine receptor } 2 \\
\text { Adenosine } 2 \text { a receptor/Purinergic receptor } 2 \\
\text { Oxytocin/Vasopressin receptors } \\
\text { Angiotensin receptor } 1 / \text { Cannabinoid receptor } 1\end{array}$ & $\begin{array}{l}{[68]} \\
{[69]} \\
{[70]} \\
{[71]} \\
{[72,73]} \\
{[10]} \\
{[10]} \\
{[73]} \\
{[72]} \\
{[10]} \\
{[54]}\end{array}$ \\
\hline TR-FRET & $\begin{array}{l}\delta \text {-Opioid receptor } \\
\beta_{2} \text { Adrenoceptor } / \delta \text { Opioid receptors } \\
\text { Histamine } 4 \text { receptor } \\
\mathrm{GABAR}_{1} / \mathrm{GABAR}_{2}\end{array}$ & $\begin{array}{l}{[74]} \\
{[74]} \\
{[75]} \\
{[76]}\end{array}$ \\
\hline
\end{tabular}




\section{G-Proteins are Powerful Regulator of GPCR Signaling}

As discussed above, GPCRs respond to distinct ligands and exert an important morphological, biochemical, physiological and pathological role in a receptor selective manner. Upon activation, GPCRs couple to heterotrimeric G-proteins resulting in the dissociation of a heterotrimeric complex of $G_{\alpha \beta \gamma}$ into $G_{\alpha}$ subunit and $G_{\beta \gamma}$, which in turn activates downstream signaling via different isoforms of adenylyl cyclase (AC) [77-80]. Studies have shown the vast diversity following interaction between GPCRs and $G$ proteins in activation of various signaling pathways [79]. Heterotrimeric G-proteins are generally classified into four families based upon the similarity in amino acid sequences: $G_{s}, G_{i}, G_{q}$ and $G_{12}$ [81]. A concise description of some of the GPCRs coupling with distinct $G$ proteins $\left(G_{i}, G_{s}\right.$ and $\mathrm{G}_{\mathrm{q}}$ ) is described in Table 2 .

Table 2. Examples of GPCRs coupling to certain $G$ Protein subclasses $\left(G_{i}, G_{s}\right.$ and $\left.G_{q}\right)$.

\begin{tabular}{|l|l|l|}
\hline G Protein & Receptor Subtypes & References \\
\hline & Chemokine Receptor & {$[82]$} \\
& Opioid Receptor & {$[83]$} \\
& Somatostatin Receptor & {$[84]$} \\
& Neuropeptide Y Receptor & {$[85]$} \\
& Melatonin Receptor & {$[86]$} \\
& Cannabinoid Receptor & {$[87]$} \\
& Sphingosine-1-phosphate Receptor & {$[88]$} \\
& Histamine Receptor & {$[87]$} \\
& 5-hydroxytryptamine & {$[89]$} \\
& Dopamine Receptor & {$[87]$} \\
& Muscarinic Receptor & {$[90,91]$} \\
& Formyl-methionyl peptide Receptor & {$[92]$} \\
\hline \multirow{5}{*}{ protein } & Vasopressin receptor 2 & {$[87]$} \\
& Adrenoceptors & {$[93]$} \\
& Prostaglandin E receptor subtypes & {$[94]$} \\
& 5-hydroxytryptamine receptor subtypes & {$[89]$} \\
& Melanocyte-stimulating hormone receptor & {$[95]$} \\
& Melanocortin receptor subtypes & {$[96]$} \\
& Relaxin receptor subtypes & {$[97]$} \\
& Adenosine receptor & {$[98]$} \\
\hline $\mathbf{q}$ protein & Vasopressin receptor subtypes (V1a and V1b) & {$[87,99]$} \\
& Muscarinic acetylcholine receptor subtypes & {$[90]$} \\
& Gonadotropin-releasing hormone receptor & {$[100]$} \\
& P2Y purinoceptor subtypes & {$[101,102]$} \\
& Bradykinin receptor subtypes & {$[103]$} \\
& Oxytocin receptors subtypes & {$[99]$} \\
& Gastrin/cholecystokinin type B receptor & {$[104]$} \\
& Neuromedin U Receptor subtypes & {$[105]$} \\
& Neurotensin Receptor & {$[106]$} \\
\hline
\end{tabular}


Table 2. Cont.

\begin{tabular}{|l|l|l|}
\hline G Protein & Receptor Subtypes & References \\
\hline \multirow{2}{*}{$\mathbf{G}_{\mathbf{i} / \mathbf{s}}$ proteins } & Glycoprotein hormone receptors & {$[107]$} \\
& $\beta$-Adrenoceptors & {$[108,109]$} \\
\hline \multirow{3}{*}{$\mathbf{G}_{\mathbf{i} / \mathbf{q}}$ proteins } & Platelet activating factor receptor & {$[87]$} \\
& Sphingolipid (S1P3)/Lysophospholipid receptor (LPA2) & {$[81]$} \\
& Galanin receptor 2 & {$[110]$} \\
& Endothelin B & {$[111]$} \\
\hline \multirow{3}{*}{$\mathbf{G}_{\mathbf{q} / \mathbf{s}}$ proteins } & Calcitonin Receptor & {$[112]$} \\
& Parathyroid hormone receptor & {$[113]$} \\
& Cholecystokinin-A receptor & {$[87]$} \\
\hline \multirow{3}{*}{$\mathbf{G}_{\mathbf{q} / / \mathbf{s}}$ proteins } & Prostaglandin E3 receptor & {$[94]$} \\
& Thyrotropin receptor & {$[107]$} \\
& Luteinizing hormone receptor & {$[87]$} \\
& Lysophospholipid receptor subtypes & {$[114,115]$} \\
\hline
\end{tabular}

Data presented in this table has been generated from the following references $[81,87,116-118]$.

At large, $\mathrm{G}_{\mathrm{s}}$ is related with the activation of $\mathrm{AC}$ isoforms 1-9. Functionally, increased production of cAMP as the second messenger via activation of $A C$ is associated with the GPCR's signaling via $G_{s}$ protein (Figure 1A) [79]. $\mathrm{G}_{\mathrm{i}}$ inhibits $\mathrm{AC}$ isoforms 5 and 6. Physiological response of many hormones and neurotransmitters like dopamine, epinephrine, and somatostatin (SST) is via $\mathrm{G}_{\mathrm{i}}$ protein. Members of the $G_{i}$ family are pertussis toxin (PTX) sensitive as it blocks the receptor coupling and downstream signaling by catalyzing ADP ribosylation of position 4 cysteine residue in the $\alpha$ subunit of $C$-terminal (Figure 1B). $\mathrm{G}_{\mathrm{q}}$ activates PLC $\beta 1-4$ and this pathway is activated by calcium-mobilizing hormones which in turn leads to the activation of PLC that activate intracellular messengers inositol trisphosphate (IP3) and diacylglycerol (DAG) [79]. IP3 is involved in calcium release whereas DAG is associated with protein kinase $\mathrm{C}(\mathrm{PKC})$ recruitment (Figure $1 \mathrm{C})$. In contrast, $\mathrm{G}_{12}$ is involved with the Rho-guanine nucleotide exchange factor (Figure 1D). On the other hand, there are many receptors which have shown multiple $G$ protein coupling. Recent studies have shown association of single GPCR with multiple $\mathrm{G}$ proteins like $\mathrm{G}_{\mathrm{i} / \mathrm{s}}, \mathrm{G}_{\mathrm{q} / \mathrm{s}}, \mathrm{G}_{\mathrm{i} / \mathrm{q}}, \mathrm{G}_{\mathrm{q} / \mathrm{i} / \mathrm{s}}$ proteins. The coupling of GPCRs to different G-proteins is the physiological manifestation and pharmacological characterization of the diversity in the receptor signaling in cell and tissue dependent manner. The association of receptors to distinct $G$ protein is responsible for the activation of specific effector molecule and stimulation of diverse signaling cascades responsible for varied biological effects by a single receptor. $\beta$-ARs, generally believed to couple $G_{s}$ may also bind to $G_{i}$ for signaling under the influence of protein kinase A (PKA) $[108,109]$. Upon agonist activation, $\beta$-ARs couple to $A C$ in $G_{s}$ dependent manner which subsequently increases intracellular cAMP levels. Conversely, $\beta$-ARs when coupled to $\mathrm{G}_{\mathrm{i}}$, activate distinct signaling cascades through the inhibition of cAMP [119-121]. Coupling to multiple G proteins is not limited to the $\beta$ ARs, other receptors like ORs which couples to $G_{i}$ have also shown coupling with $G_{s}$ [122]. In general, SST exert inhibitory effect on AC however, studies have also described dual effect of SST in dose dependent manner in somatotrophs of porcine origin with increased cAMP at low and high concentration [123]. Although receptor subtype associated with such dual effect of SST is not known however SST coupling to different G protein has been speculated [124]. The functional impacts of 
different $\mathrm{G}$ proteins on homeostasis, embryonic and gonadal development as well as in learning and memory have been described elsewhere in details [79,125]. Importantly, it is worth of investigation to elucidate the role of different $G$ proteins in SSTRs heterodimerization, modulation of receptor mediated signalling and its relevance to pathological conditions.

Figure 1. Schematic presentation depicting the regulation of receptor signaling through G-proteins. GPCRs upon activation couples to $\mathrm{G}_{\alpha \mathrm{s}}(\mathbf{A}), \mathrm{G}_{\alpha \mathrm{i}}(\mathbf{B}), \mathrm{G}_{\alpha \mathrm{q}}(\mathbf{C})$ or $\mathrm{G}_{\alpha 12}(\mathbf{D})$ and regulates signaling in specific manner. Downstream signaling involving $G_{\beta \gamma}$ subunit is depicted in panel A [78,79,81]. Figure was made by using the online pathway builder from Protein Lounge [126].
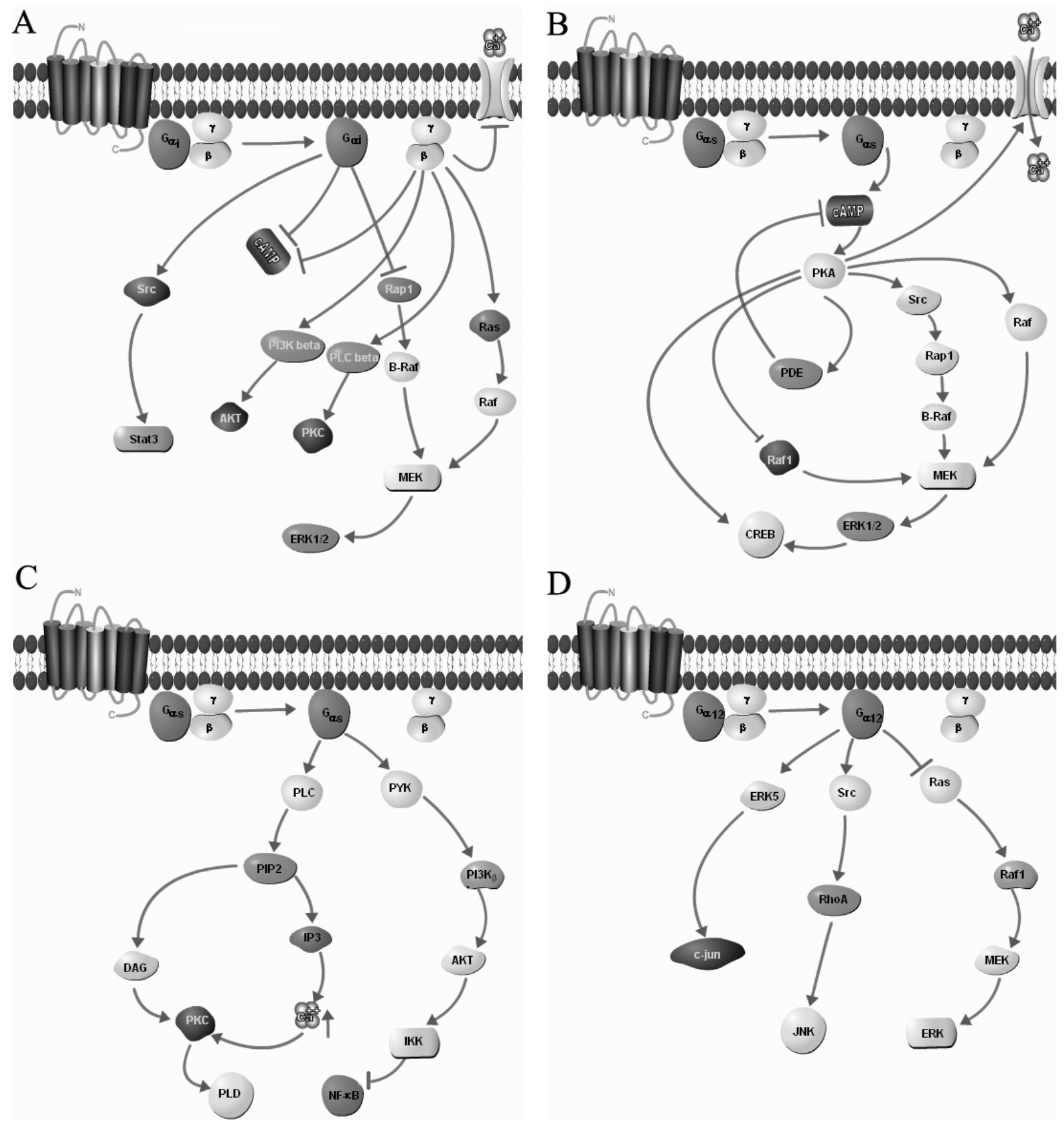


\section{Homo- and Heterodimerization of GPCRs}

Fraser and Venter, using immuno-affinity chromatography and Western blot analysis, put forth direct evidence for the first time for $\beta_{2} \mathrm{AR}$ dimerization in cells of lung origin [127]. Similarly, Paglin and Jamieson came forward with their observations on covalent cross-linking of angiotensin receptor 2 to its binding sites in rat adrenal membrane [128]. Furthermore, number of other receptors were identified in larger entity than expected monomeric size by using radiation inactivation and photoaffinity labeling experiments [129].

The physical evidence for GPCRs dimerization were further supported with studies involving GABA receptors, where receptor functionality and sorting to the cell surface was dependent upon dimerization with other subtypes [130]. The ER retention signal of the $G_{A B A} R 1$ was masked upon heterodimerization with $\mathrm{GABA}_{\mathrm{B}} \mathrm{R} 2$ leading to proper sorting of the receptors to the cell surface [131]. Further, interaction of both the receptors subtypes was critical for the signaling specifically $G_{A B} A_{B} R$ for the ligand binding and $\mathrm{GABA}_{\mathrm{B}} \mathrm{R} 2$ for the G-protein coupling. Cells expressing taste receptors (TRs)-T1R1, T1R2 or T1R3, were insensitive to taste stimuli, whereas heterodimerization of T1R1 with T1R2 and T1R3 was shown to be required for sensation of sweet and umami taste [132]. Although the formation of functional receptor complex upon heterodimerization of two non-functional receptors was often described, dimerization of two functional receptors was shown for the first time for $\delta$ and $\kappa$ ORs. This interaction resulted in distinct ligand binding efficiency of the receptor complex [133]. Homo- and heterodimerization of ORs imparted distinct pharmacological and functional properties to the receptor in comparison to its monomers [50,70,134]. Many other unrelated studies also suggested dimerization as the basic requirement for GPCRs signaling. Interestingly, studies have also shown receptor monomers as the functional units for example SSTR1 as discussed in details at later point in this review [21].

Radioligand binding studies indicated that SSTR2 is the most prominent receptor subtype expressed in the murine central nervous system (CNS). SSTR2 knock out $(k o)$ animals displayed significant loss in SST binding in comparison to other SSTR ko animals [135]. Furthermore, the changes in the pharmacological properties of SSTR subtypes upon homo- and/or heterodimerization might also be responsible for the loss of SST binding in ko animals [136,137]. In contrast to our previous studies in SST ko mice, no compensatory changes in other SSTRs expression were observed in SSTR2 ko mice [135,138]. On a similar note, distinct pharmacological properties of SSTRs observed in cells and neoplastic tissues indicate the existence of additional undiscovered SSTR subtypes. However, SSTRs interaction leading to the formation of homo- and/or heterodimers might be the possible explanation for the distinct pharmacological properties [137,139-141]. By using a combination of morphological, pharmacological, biochemical and biophysical techniques, there are strong evidences for dimerization of SSTRs in agonist dependent manner [15,17,21,30,31,34,35,37,40,52,53,63,64]. The concept of SSTR dimerization was first demonstrated for the SSTR5 subtype using Photobleaching-Fluorescence resonance energy transfer (Pb-FRET) analyses [21]. SSTR subtypes homo- and heterodimerization have also been demonstrated in live cells by Fluorescence correlation spectroscopy (FCS) technique [142]. Later, using Pb-FRET analysis it was demonstrated that SSTR2, SSTR3 and SSTR4 exist as preformed dimers and respond distinctly to agonist treatment $[32,36,38]$. SSTR1 is the only receptor subtype which exists as monomer irrespective of agonist induced activation [21]. A most interesting 
result for homodimerization was observed for SSTR2 in different species (human, rat or porcine), which exists as constitutive homodimer in the basal condition and dissociates into monomers upon agonist treatment $[32,52,63]$. These studies cumulatively suggest that dissociation of SSTR2 in all species is a prerequisite for receptor internalization. Interestingly, elegant observation in porcine SSTR2 demonstrated reassociation of the receptors as dimers immediately after dissociation [63].

Furthermore, in addition to homodimerization, SSTRs also exhibit heterodimerization within the family. SSTR1/5, SSTR2/5, SSTR4/5 and SSTR2/3 display heterodimerization whereas SSTR1/4 does not form heterodimers in basal or upon agonist treatment [21,31,34,36,52]. hSSTR2/hSSTR3 heterodimerization was induced by SSTR2 selective agonist only whereas endogenous pan-agonist SST-14 has shown to enhance hSSTR1/hSSTR5 heterodimers formation [21,31,34,142]. SSTR2 and SSTR3 of rodent origin displayed SSTR2 like characteristics upon heterodimerization, but also exhibit relatively greater resistance to agonist-induced desensitization [52]. SSTR2-mediated SSTR3 inactivation upon heterodimerization was also observed in the cerebellum of developing rat brain that exhibit high levels of SSTR2 and SSTR3 mRNA expression whereas display absence of SSTR3 binding sites [143]. SSTRs are also shown to form heterodimers with receptors of other members of GPCR family. Previous studies from authors lab have demonstrated heterodimerization of D2R with SSTR2 and SSTR5 and its regulation by agonist-binding [30,35]. Heterodimerization between SSTR2 and the $\mu$-opioid receptor did not altered the ligand binding properties of receptor but modulates the receptors phosphorylation, desensitization and internalization [53]. Recently, we have also shown the receptor and ligand dependent heterodimerization of $\beta$-ARs with SSTR5 in regulation of receptor expression and downstream signaling in heterologous system $[37,40]$.

Later, another insight for GPCRs homo/heterodimerization was introduced from studies demonstrating ligand-induced regulation of GPCR dimerization. For the members of Class A GPCR subfamilies, co-activation of the receptors in the dimer pair has been shown as a prerequisite for the stabilization of heterodimers [62,72,144-147], whereas activation of one interacting receptor protomers was also found to equally foster heteromeric interactions [30,33-35,148]. Like CXCR4 (chemokine receptor 4), SSTR5 exist in monomeric state and homodimerization is enhanced upon activation with their respective ligands $[34,149]$. Constitutive SSTR4 dimers display an enhanced dimerization upon ligand activation whereas ligand binding induces a reverse effect on SSTR3 homodimers [36,38]. In contrast, dissociation of preformed human thyrotropin receptor and Neuropeptide Y4 receptor homodimers was induced upon agonist activation [150,151]. Ligand binding is not always critical regulator of receptor dimerization, some of the receptors have been shown insensitive to ligand such as melatonin receptor 1 (MTR1) and the murine SSTR2 and SSTR3 heterodimers [52,152]. Recently, we have shown that SSTR5 and $\beta A R$ heterodimerization reduces upon agonist treatment whereas combined agonist treatment fosters this interaction [37]. In contrast, dissociation of receptor homodimers was also suggested essential for proper receptor trafficking. For instance, dissociation of $\delta \mathrm{OR}$ homodimers promotes down regulation of the receptors at the membrane and blocking this dissociation by using cross-linking reagents resulted in the impaired internalization process [134]. Similar observations have also been made for SSTR2, as ligand activation induces dissociation of receptor homodimers and receptor internalization [32]. However, in contrast internalization was increased in case of the platelet activating factor receptor and the thyrotropin-releasing hormone receptor upon dimerization [153,154]. 


\section{Implications of Structural Domains in GPCR Dimerization}

Several previous studies have revealed the functional significance and involvement of different structural domains of GPCRs in the process of homo- and/or heterodimerization. Apart from the critical role played by the different structural domains of GPCR in receptor dimerization, these structural domains are also crucial for eliciting physiological, functional and pharmacological properties of the receptors. Many structural interfaces have been anticipated as critical contributors for the GPCRs dimerization including the amino terminal domain, intracellular loops, transmembrane domains and $C$-terminal. $N$-terminal of GPCRs is of variable size in different receptors and plays critical role in protein folding, intracellular trafficking and ligand binding. For GABA receptors, $N$-terminal of the $G_{A B A} R 1$ and $G_{B B A} R 2$ subunits are essential for the coupling of $G_{B B A}$ receptors to $G_{i}$ and $G$ protein activated K channels (GIRKs) [155]. Similarly, $N$-terminal variants of serotonin receptor (5-HT) and $\mu \mathrm{OR}$ have shown altered ligand binding in comparison to the wild types whereas $N$-terminal variants of $\beta_{2} \mathrm{AR}$ displayed changes in the agonist mediated receptor internalization [156-158]. 5-HT receptor also display modulated receptor trafficking whereas no distinct change in ligand binding was observed [159]. The extracellular amino-terminal domain has been shown to be critical for the glutamate receptor and CaSRs dimerization $[160,161]$ as well as for the bradykinin 2 receptor (B2R) homodimerization [162]. Dimerization of glutamate and CaSR is via disulphide linkage between cysteine residues of $\mathrm{N}$-terminal which is significantly altered upon mutations in Cysteine residues of $N$-terminal [160,163,164].

$C$-terminal of GPCRs act as a potential site for G-protein receptor kinase (GRKs) mediated phosphorylation, desensitization as well as palmitoylation. The $C$-terminal has been associated in the dimerization for the $\mathrm{GABA}_{\mathrm{B}} \mathrm{Rs}$ and $\alpha \mathrm{OR}[56,134]$. The $\mathrm{GABA}_{\mathrm{B}} \mathrm{R}$ dimerize via the cytoplasmic tail ( $C$-tail) in the endoplasmic reticulum a process independent of ligand activation [56,57,165]. SSTR subtypes present a very unique scenario where each member behaves in a different way for homoand/or heterodimerization. Importantly, $C$-tail is critical determinant of SSTR dimerization in receptor specific manner. The $C$-tail is markedly not a prerequisite in case of SSTR3 homodimers whereas, SSTR4 losses the capability of homo- and heterodimerization with the deletion of C-tail [36,38]. Switching SSTR4 C-tail with SSTR1 resulted in a chimeric SSTR4 which displays impaired surface expression and dimerization. Interestingly, in the presence of the $C$-tail of SSTR5, SSTR4 retains the capability of homodimerization [36]. While these studies delineate $C$-tail as a crucial factor in SSTRs oligomerization specifically negative role of SSTR1 $C$-tail in dimerization, future studies will be of pharmacological significance once the composition of amino acid in C-tail of SSTR1 responsible for this effect is determined.

Transmembrane domains embedded in the membrane are $\alpha$-helical structures. Variation in $\alpha$-helices of D4R, follicle-stimulating hormone receptor (FSHR) and vasopressin receptor 2 (V2R) resulted in attenuated ligand binding, altered coupling to adenylyl cyclase and defective receptor trafficking respectively [166-168]. Intracellular loops (ICLs) are implicated in receptor signaling as well as for interactions with regulatory proteins like arrestins or GRKs. Mutations in ICL of D2R, endothelin receptor (ETbR) and V2R alters receptor coupling to G proteins [166]. The TMs, extracellular loop (ECL) and ICLs for several GPCRs are implicated in the process of dimerization including rhodopsin 
receptors, DRs (ICL III), $\beta$-ARs (TMD VIth) and $\alpha_{1 b}$-adrenoreceptor $[28,30,169,170]$. Additionally, homodimerization of CXCR2 involves multiple regions including ECL1, TM III, and ICL II [51].

\section{GPCR Trafficking and Ligand Binding Is Altered upon Dimerization}

Functional diversification of receptors dimerization has been observed in ligand binding, trafficking and signal transductions. Depending upon the receptor status, ligands have distinct affinity and accessibility to the binding sites. For instance, enhanced ligand binding for purinergic receptor (P2Y1) and decreased ligand binding for $\alpha$-AR has been shown following the formation of heterodimers [171]. There are many such evidences to support the fact that one of the receptor in dimer pair modulates the properties of the partner receptor. For instance, muscarinic receptor (MR) subtypes M2R and M3R have distinct pharmacological properties upon heterodimerization in comparison to its monomers [42]. $\beta_{2} \mathrm{AR}$ mediated airway smooth muscle relaxation is reduced upon heterodimerization with prostaglandin E1 receptor (EP1) whereas the $\beta_{2} \mathrm{AR}$ displayed enhanced affinity for the ligand upon heterodimerization with $\beta_{1}$ AR [148]. Similar changes in the ligand binding affinity of $\mu, \delta$, and $\kappa$ receptors agonist were observed upon $\delta \mathrm{OR}$ and $\kappa \mathrm{OR} / \mu \mathrm{OR}$ heterodimerization $[49,133]$. Heterodimers of $\mu \mathrm{OR}$ and $\delta \mathrm{OR}$ were shown to be PTX insensitive whereas the monomers and homodimers were sensitive [49].

Heterodimerization may provide negative or positive cooperativity to the ligand binding. SSTR2 and SSTR3 forms constitutive heterodimers and display significant reductions in binding affinity for SSTR3-selective agonist L-796,778 [52]. Furthermore, SSTR3/2 heteromeric complex exhibit SSTR2 like properties in GTP binding, inhibition of AC, and phosphorylation of extracellular regulated kinases (ERK1/2). In case of D2R/SSTR2 heterodimers, positive cooperativity was observed for D2R, as the agonist-bound SSTR2 significantly enhanced binding affinity of D2R [30,35]. In addition, simultaneous activation of two interacting protomers enhanced downstream signaling efficiency. Moreover, the modulation of endocytic properties of bradykinin B2 and angiotensin AT1 receptors have also been observed upon heterodimerization [172]. Studies have demonstrated selective preferences of certain docking proteins in receptor internalization in homo- and/or heteromeric complexes. Homodimers were shown to internalize in a clathrin and dynamin dependent manner whereas heterodimers endocytosed in a dynamin dependent manner only [172]. These receptor pairs also display switching in the coupling to $G$-proteins from $G_{q}$ to $G_{i}$ upon heterodimerization when compared with homodimers respectively. $\beta_{1} \mathrm{AR}$ upon heterodimerization with $\beta_{2} \mathrm{AR}$ resulted in internalization resistant complex, where the internalization property of $\beta_{2} \mathrm{AR}$ was compromised in the presence of internalization resistant $\beta_{1} \mathrm{AR}$ [68].

\section{Implication of GPCR Heterodimers in Pathophysiological conditions}

The concept of GPCRs heterodimerization and its association with many pathological conditions is now well appreciated. Several studies have shown that GPCRs in a heterodimeric complex elicit a significant role in a number of diseases at different stages, either via regulating the pathological condition or towards its progression by modulating selective downstream signaling cascades. Some of the pathological conditions associated with receptor dimerization are discussed briefly. 
Acquired immune deficiency syndrome: Human immunodeficiency virus (HIV) at different stages of infection uses chemokine receptors as co-receptors. Interaction of a mutant for chemokine receptor 2 (CCR2) with CCR5 or C-X-C chemokine receptor type 4 (CXCR4) result in a blockade or delay of HIV infection due to the inability of the virus to bind these later receptors [173]. The heterodimerization between CCR2 mutant CCR2V64I with CXCR4 may result in decreased levels of CXCR4 in peripheral blood mononuclear cells resulting in the delayed progression of the disease $[173,174]$.

Asthma: Heterodimers of EP1/ $\beta_{2} \mathrm{AR}$ receptor plays a critical role in progression of asthma [148]. EP1 receptor in monomeric form has no physiological significance whereas upon heterodimerization with $\beta_{2} \mathrm{AR}$ results in altered $\beta_{2} \mathrm{AR}$ conformation and decreased signaling. Heterodimerization resulted in modulation of coupling between $\mathrm{G} \alpha \mathrm{s}$ and $\beta_{2} \mathrm{AR}$ in airway smooth muscles causing reduced bronchodialatory potential of agonist [148]. The activation of EP1 receptors increases down-regulation of heterodimer pair, resulting in loss of $\beta_{2}$ AR binding to $G_{s}$ which diminishes $\beta_{2}$ AR-mediated airway smooth muscle relaxation significantly [148].

Cardiac Failure: Blockade of $\mathrm{AT}_{1} \mathrm{R}$ and $\beta$-ARs signaling has been shown beneficial in cardiac failure. $\beta$-ARs antagonist via trans-inhibition blocks Ang II mediated pathways thus regulating two different receptors mediated signaling involved in the pathophysiology of the failing heart. Studies have also demonstrated that catecholamine mediated heart rate is regulated by AT1R and $\beta_{2} A R$ heterodimers [175], whereas the regulation of cardiac contractility by $A T 1 R / \beta_{2} A R$ as well as $\beta_{1} \mathrm{AR} / \beta_{2} \mathrm{AR}$ heterodimers has been shown which regulates desensitization of $\beta_{2} \mathrm{ARs}$ upon agonist activation [176].

Preeclampsia: Several previous studies have suggested the role of $\mathrm{AT}_{1} \mathrm{R} / \mathrm{B} 2 \mathrm{R}$ heterodimers in conditions like hypertension, preeclampsia and smooth muscle cells contraction [176-178]. Studies have also suggested increased expression levels of $\mathrm{AT}_{1} \mathrm{R} / \mathrm{B} 2 \mathrm{R}$ heterodimers in renal mesengial cells of hypertensive rats in comparison to normal rats. Upregulation of $\mathrm{AT}_{1} \mathrm{R} / \mathrm{B} 2 \mathrm{R}$ heterodimers during pregnancy plays critical role in $\mathrm{AT}_{1} \mathrm{R}$ mediated hyper-responsiveness in hypertension (in preeclampsia) $[177,179,180]$ whereas Ang II mediated signaling was negatively regulated by selective inhibition of heterodimer pair [180].

Psychosis/Schizophrenia: Modulation of the 5-HT and glutamate receptor functional complex has been shown to play critical role in inclining schizophrenic patients to psychosis [181]. In untreated schizophrenia patients, increased level of the 5-HT and decreased level of glutamate receptor was observed in the post-mortem brain. Recent studies have proposed that drugs used in schizophrenia may be targeting different receptors in the serotonin/glutamate receptor heterodimer pair thus playing critical role in triggering distinct downstream cellular pathways [182].

Parkinson's Disease (PD): Heterodimerization of $\mathrm{A}_{2 \mathrm{a}} \mathrm{R}$ and $\mathrm{D} 2 \mathrm{R}$ has been exploited as a potential target in improving the side effects of L-DOPA in PD [183]. Dyskinesia (uncontrolled muscle contractions) was major issue with administration of L-DOPA for the treatment of PD initially [184]. $\mathrm{A}_{2 \mathrm{a}} \mathrm{R}$ agonist modulates cell surface expression of $\mathrm{D} 2 \mathrm{R}$ resulting in decreased binding affinity for D2R agonist [185,186] whereas the use of $\mathrm{A}_{2 \mathrm{a}} \mathrm{R}$ antagonist improves motor control without causing dyskinesia in mouse model of PD [187]. Neurodegenerative diseases hold better potential for the development of new therapeutic drugs due to the widespread distribution and complex communicating network of several members of GPCR, ionotropic glutamate receptors and RTK family in CNS. 


\section{Implication of Somatostatin Receptors Heterodimerization in Pathological Conditions}

Five SSTR subtypes in addition to have a common affluence to inhibit AC have shown unique characteristic for the formation of homo- and heterodimers with significant diversification and represents a promising target in several pathological conditions like cancer, pain, heart failure and neurological disorders [188,189].

Several previous studies have shown the expression of one or more SSTRs including SSTR2 and SSTR5 in tumor tissues of different origins like breast, prostate, pituitary and pancreas [190-193]. Many studies have also shown the co-expression of SSTRs and DRs in tumor of different origins [194]. As discussed in previous section, SSTR2 and 5 heterodimerize with D2R in vivo and in vitro experimental conditions and this association has emerged as the potential target in the treatment of pituitary adenomas [30,35,192]. Chimeric molecules targeting two receptors or three receptors have been developed and used successfully to regulate the growth hormone and prolactin secretions in vitro. These chimeric molecules (dopastatins) were developed to target SSTR2, SSTR5 and D2R as a potential target for the treatment of pituitary tumor "acromegaly" [195-199]. Several previous studies have demonstrated resistant to octreotide therapy in patients with growth hormone secreting tumors [200,201]. Recently, Castano's group suggested that SSTR mutants might result in the non-responsiveness of these patients to SST analogues therapies [64,202,203]. Mutant of SSTR5 like SST5TMD4 is expressed in normal as well as in breast tumor tissues along with other wt SSTR subtypes [204]. Moreover, the heterodimerization of SSTR2 with mutated SST5TMD4 modulates SSTR2 regulated downstream signaling and SST mediated anti-tumor effects [204].

Studies have shown that all five SSTR subtypes are variably expressed at the mRNA and protein levels in breast tumor cells [205-212]. Interestingly, SSTR expression is positively correlated with tumor size, whereas inversely correlated with EGFR expression levels and tumor differentiation [210,211]. In a number of in vitro and in vivo mammary cancer models, SST and its analogs displayed anti-tumor activity for, e.g., OCT decreases the growth of $\mathrm{ER}^{+}$cell lines in culture [213-220]. Recent studies have shown that SSTRs specifically SSTR1 and SSTR5 alters ErbB1 signaling and abrogate EGF-stimulated cell proliferation and signaling [15-17]. These observations are of significance in the pathophysiology of tumors, such as breast cancer. SSTRs interfere with the homo- and heterodimers of ErbBs and modulate the downstream signaling significantly via activating different signaling molecules thus promoting cytostatic or cytotoxic effects rather than proliferation [15-17]. The specific function of SSTRs in breast tumor is still not clear, but can be exploited for diagnostic and therapeutic approaches. Employing SST and its analogues in combination with chemotherapeutic agents might provide an additional tool to target tumours in multiple ways or to provide synergistic anti-tumor actions.

Like SST, the opioid transmitter system is also widely expressed throughout the brain and exert crucial role in pain perception, consciousness, motor control and autonomic function. These effects are mediated through ORs that comprise three subtypes $-\mu, \delta$, and $\kappa$, that are structurally related to SSTRs and share $\sim 40 \%$ sequence homology. Recent studies have demonstrated that SSTRs also play a critical role in mediating analgesic effects of SST [188,221,222]. For instance, upon direct administration to the central and peripheral nervous system in animal model of post-operative and neoplastic pain, the SST analogue octreotide is both analgesic and morphine-sparing [223,224]. Octreotide has been observed to behave as an antagonist in morphine-dependent individuals and patients undergoing 
morphine withdrawal have presented with reduced vomiting following octreotide administration [225,226]. Recent studies have shown SSTR4 and $\delta$ ORs colocalize in rat brain and spinal cord and also exhibit heterodimerization in heterologous system [39]. Pfeiffer et al., demonstrated that SSTR2 and the $\mu \mathrm{OR}$ co-localized in neurons of the locus coeruleus and SSTR2 with $\mu \mathrm{OR}$ exhibit heterodimerization in transfected cells, without any significant changes in the receptor pharmacology and signaling [53]. At present, opioids are the best available options as analgesic drugs in the treatment of pain, whereas there are several side effects associated with the prolonged use of opioids, including addiction and withdrawal. We propose that SST analogs in combination with opioid receptor agonists will minimize the side effects of opioids and thus will serve as potential safer therapeutic agent for pain relief in future.

The role of $\beta$-ARs in heart failure and cardiac complication is undisputed. Recent studies have also described that SST play an important role in regulation of cardiac contraction. There is other evidence supporting the fact that $30-40 \%$ deaths in Huntington's disease and pituitary tumor (acromegaly) are due to heart failure [227,228]. Whether the gradual loss of SST, uncontrolled GH and IGF-1 secretion, or the modulation of cellular functions are responsible for heart failure is not yet clear. Importantly, these studies support intimate association between SST and heart failure. Recent studies have shown direct evidence that SSTR subtypes functionally interact with $\beta$-ARs [37,40]. Previous studies as early as in 1985 pointed out this association and provided the evidence that $\beta$-AR mediated cAMP was enhanced in presence of SST in astrocytes prepared from rat brain without displaying any changes in $\beta$-AR binding properties [229]. Interestingly, in cultured astrocytes SST alone has no effect on cAMP. SST has been shown to promote the membrane translocation of $\beta$-AR kinase similar to the effect of isoproterenol. The presence of cytosolic enzyme $\beta$-AR kinase is a prerequisite for $\beta$-AR phosphorylation in presence of agonist [230]. Recent studies from HEK-293 cells stably transfected with SSTR5 and $\beta$-ARs have shown the existence of basal heterodimers strengthen the concept of functional interaction between adrenergic and somatostatinergic system with possible role in cardiac tissue [37,40,231]. Future studies involving SSTR and $\beta$-AR subtypes will uncover the role of SSTR and AR subtypes in the cardiovascular system. Most importantly, studies directed in experimental condition when $\beta$-ARs switch their coupling from $G_{s}$ to $G_{i}$ will be of particular interest in combination with SSTR subtypes.

\section{Conclusions}

At the time that this review was written, it was well established and largely accepted that GPCRs function in an integrated manner as homodimers and/or heterooligomers and serve as potential platform for the development of new therapeutic approaches in certain pathological conditions. There are many other members of GPCR family which have not been explored for their exact physiological functions in a heteromeric complex yet. The development of new methodology to elucidate the distributional pattern and receptor orientation in heteromeric complex at cell surface will help in delineating the protein-protein interaction and physiological significance of such complex formation. However, additional studies are warranted specifically in a system where these receptors are expressed endogenously like in CNS, often expressing more than one receptor in a single cell. Considering these examples as described in this review amplifies the concept that it is the heteromeric complexes and not monomers which are playing critical role in regulating most if not all pathophysiological conditions. 
The intensity of heterodimers is sometimes elevated in diseased conditions and only thus becomes an easy target for drugs. Modulation of receptor functions, signaling and more significantly the expression level has been proven critical upon heterodimerization and compounds regulating these functions have proved beneficial in many diseases including pituitary adenomas. Taken in consideration drugs targeting specifically heteromeric complex would be new therapeutic interventions in the time to come.

\section{Acknowledgments}

The work cited in this review from authors' laboratory referred to human somatostatin receptors was supported by Canadian Institute of Health Research Grant (MOP 10268 and MOP 74465) and grant from Canadian Breast Cancer Foundation BC/Yukon to U.K, who is a Senior Scholar of the Michael Smith Foundation for Health Research.

\section{References}

1. Fredholm, B.B.; Hokfelt, T.; Milligan, G. G-protein-coupled receptors: An update. Acta Physiol. (Oxf.) 2007, 190, 3-7.

2. Attwood, T.K.; Findlay, J.B. Fingerprinting G-protein-coupled receptors. Protein Eng. 1994, 7, 195-203.

3. Kolakowski, L.F., Jr. GCRDb: A G-protein-coupled receptor database. Recept. Channels 1994, 2, 1-7.

4. Bockaert, J.; Pin, J.P. Molecular tinkering of g protein-coupled receptors: An evolutionary success. EMBO J. 1999, 18, 1723-1729.

5. Fredriksson, R.; Lagerstrom, M.C.; Lundin, L.G.; Schioth, H.B. The G-protein-coupled receptors in the human genome form five main families. Phylogenetic analysis, paralogon groups, and fingerprints. Mol. Pharmacol. 2003, 63, 1256-1272.

6. Fredriksson, R.; Schioth, H.B. The repertoire of G-protein-coupled receptors in fully sequenced genomes. Mol. Pharmacol. 2005, 67, 1414-1425.

7. Millar, R.P.; Newton, C.L. The year in G protein-coupled receptor research. Mol. Endocrinol. 2010, 24, 261-274.

8. Milligan, G. G protein-coupled receptor dimerization: Function and ligand pharmacology. Mol. Pharmacol. 2004, 66, 1-7.

9. Pagano, A.; Rovelli, G.; Mosbacher, J.; Lohmann, T.; Duthey, B.; Stauffer, D.; Ristig, D.; Schuler, V.; Meigel, I.; Lampert, C.; et al. C-terminal interaction is essential for surface trafficking but not for heteromeric assembly of GABA(B) receptors. J. Neurosci. 2001, 21, 1189-1202.

10. Terrillon, S.; Durroux, T.; Mouillac, B.; Breit, A.; Ayoub, M.A.; Taulan, M.; Jockers, R.; Barberis, C.; Bouvier, M. Oxytocin and vasopressin V1a and V2 receptors form constitutive homo- and heterodimers during biosynthesis. Mol. Endocrinol. 2003, 17, 677-691.

11. Pidasheva, S.; Grant, M.; Canaff, L.; Ercan, O.; Kumar, U.; Hendy, G.N. Calcium-sensing receptor dimerizes in the endoplasmic reticulum: Biochemical and biophysical characterization of CASR mutants retained intracellularly. Hum. Mol. Genet. 2006, 15, 2200-2209.

12. Monyer, H.; Sprengel, R.; Schoepfer, R.; Herb, A.; Higuchi, M.; Lomeli, H.; Burnashev, N.; Sakmann, B.; Seeburg, P.H. Heteromeric NMDA receptors: Molecular and functional distinction of subtypes. Science 1992, 256, 1217-1221. 
13. Watt, H.L.; Kharmate, G.; Kumar, U. Biology of somatostatin in breast cancer. Mol. Cell. Endocrinol. 2008, 286, 251-261.

14. Earp, H.S.; Dawson, T.L.; Li, X.; Yu, H. Heterodimerization and functional interaction between EGF receptor family members: A new signaling paradigm with implications for breast cancer research. Breast Cancer Res. Treat. 1995, 35, 115-132.

15. Kharmate, G.; Rajput, P.S.; Watt, H.L.; Somvanshi, R.K.; Chaudhari, N.; Qiu, X.; Kumar, U. Dissociation of epidermal growth factor receptor and ErbB2 heterodimers in the presence of somatostatin receptor 5 modulate signaling pathways. Endocrinology 2011, 152, 931-945.

16. Watt, H.L.; Kharmate, G.D.; Kumar, U. Somatostatin receptors 1 and 5 heterodimerize with epidermal growth factor receptor: Agonist-dependent modulation of the downstream MAPK signalling pathway in breast cancer cells. Cell. Signal. 2009, 21, 428-439.

17. Kharmate, G.; Rajput, P.S.; Watt, H.L.; Somvanshi, R.K.; Chaudhari, N.; Qiu, X.; Kumar, U. Role of somatostatin receptor 1 and 5 on epidermal growth factor receptor mediated signaling. Biochim. Biophys. Acta 2011, 1813, 1172-1189.

18. Milligan, G.; Bouvier, M. Methods to monitor the quaternary structure of G protein-coupled receptors. FEBS J. 2005, 272, 2914-2925.

19. Thomas, P.; Smart, T.G. Hek293 cell line: A vehicle for the expression of recombinant proteins. J. Pharmacol. Toxicol. Methods 2005, 51, 187-200.

20. Sarramegna, V.; Talmont, F.; Demange, P.; Milon, A. Heterologous expression of G-protein-coupled receptors: Comparison of expression systems from the standpoint of large-scale production and purification. Cell. Mol. Life Sci. 2003, 60, 1529-1546.

21. Rocheville, M.; Lange, D.C.; Kumar, U.; Sasi, R.; Patel, R.C.; Patel, Y.C. Subtypes of the somatostatin receptor assemble as functional homo- and heterodimers. J. Biol. Chem. 2000, 275, 7862-7869.

22. Maggio, R.; Vogel, Z.; Wess, J. Coexpression studies with mutant muscarinic/adrenergic receptors provide evidence for intermolecular "Cross-talk" between G-protein-linked receptors. Proc. Natl. Acad. Sci. USA 1993, 90, 3103-3107.

23. Monnot, C.; Bihoreau, C.; Conchon, S.; Curnow, K.M.; Corvol, P.; Clauser, E. Polar residues in the transmembrane domains of the type 1 angiotensin ii receptor are required for binding and coupling. Reconstitution of the binding site by co-expression of two deficient mutants. J. Biol. Chem. 1996, 271, 1507-1513.

24. Osuga, Y.; Hayashi, M.; Kudo, M.; Conti, M.; Kobilka, B.; Hsueh, A.J. Co-expression of defective luteinizing hormone receptor fragments partially reconstitutes ligand-induced signal generation. J. Biol. Chem. 1997, 272, 25006-25012.

25. Schoneberg, T.; Sandig, V.; Wess, J.; Gudermann, T.; Schultz, G. Reconstitution of mutant V2 vasopressin receptors by adenovirus-mediated gene transfer. Molecular basis and clinical implication. J. Clin. Invest. 1997, 100, 1547-1556.

26. Schoneberg, T.; Yun, J.; Wenkert, D.; Wess, J. Functional rescue of mutant V2 vasopressin receptors causing nephrogenic diabetes insipidus by a co-expressed receptor polypeptide. EMBO J. 1996, 15, 1283-1291. 
27. Schulz, A.; Grosse, R.; Schultz, G.; Gudermann, T.; Schoneberg, T. Structural implication for receptor oligomerization from functional reconstitution studies of mutant V2 vasopressin receptors. J. Biol. Chem. 2000, 275, 2381-2389.

28. Hebert, T.E.; Moffett, S.; Morello, J.P.; Loisel, T.P.; Bichet, D.G.; Barret, C.; Bouvier, M. A peptide derived from a beta2-adrenergic receptor transmembrane domain inhibits both receptor dimerization and activation. J. Biol. Chem. 1996, 271, 16384-16392.

29. Casado, V.; Cortes, A.; Mallol, J.; Perez-Capote, K.; Ferre, S.; Lluis, C.; Franco, R.; Canela, E.I. GPCR homomers and heteromers: A better choice as targets for drug development than GPCR monomers? Pharmacol. Ther. 2009, 124, 248-257.

30. Baragli, A.; Alturaihi, H.; Watt, H.L.; Abdallah, A.; Kumar, U. Heterooligomerization of human dopamine receptor 2 and somatostatin receptor 2 co-immunoprecipitation and fluorescence resonance energy transfer analysis. Cell. Signal. 2007, 19, 2304-2316.

31. Grant, M.; Alturaihi, H.; Jaquet, P.; Collier, B.; Kumar, U. Cell growth inhibition and functioning of human somatostatin receptor type 2 are modulated by receptor heterodimerization. Mol. Endocrinol. 2008, 22, 2278-2292.

32. Grant, M.; Collier, B.; Kumar, U. Agonist-dependent dissociation of human somatostatin receptor 2 dimers: A role in receptor trafficking. J. Biol. Chem. 2004, 279, 36179-36183.

33. Grant, M.; Kumar, U. The role of G-proteins in the dimerisation of human somatostatin receptor types 2 and 5. Regul. Pept. 2010, 159, 3-8.

34. Grant, M.; Patel, R.C.; Kumar, U. The role of subtype-specific ligand binding and the C-tail domain in dimer formation of human somatostatin receptors. J. Biol. Chem. 2004, 279, 38636-38643.

35. Rocheville, M.; Lange, D.C.; Kumar, U.; Patel, S.C.; Patel, R.C.; Patel, Y.C. Receptors for dopamine and somatostatin: Formation of hetero-oligomers with enhanced functional activity. Science 2000, 288, 154-157.

36. Somvanshi, R.K.; Billova, S.; Kharmate, G.; Rajput, P.S.; Kumar, U. C-tail mediated modulation of somatostatin receptor type-4 homo- and heterodimerizations and signaling. Cell. Signal. 2009, 21, 1396-1414.

37. Somvanshi, R.K.; War, S.A.; Chaudhari, N.; Qiu, X.; Kumar, U. Receptor specific crosstalk and modulation of signaling upon heterodimerization between beta(1)-adrenergic receptor and somatostatin receptor-5. Cell. Signal. 2011, 23, 794-811.

38. War, S.A.; Somvanshi, R.K.; Kumar, U. Somatostatin receptor-3 mediated intracellular signaling and apoptosis is regulated by its cytoplasmic terminal. Biochim. Biophys. Acta 2011, 1813, 390-402.

39. Somvanshi, R.K.; Chaudhari, N.; Bonnett, J.; Kharmate, G.; Rajput, P.S.; Qiu, X.; Cairns, B.E.; Kumar, U. Somatostatin receptor-4 and delta-opioid receptor heterodimerization modulates signaling pathways mediating analgesic responses. In 2010 Neuroscience Meeting, San Diego, CA, USA, 13-17 November, 2010.

40. Somvanshi, R.K.; Chaudhari, N.; Qiu, X.; Kumar, U. Heterodimerization of beta2 adrenergic receptor and somatostatin receptor 5: Implications in modulation of signaling pathway. J. Mol. Signal. 2011, 6, 9. 
41. Bai, M.; Trivedi, S.; Kifor, O.; Quinn, S.J.; Brown, E.M. Intermolecular interactions between dimeric calcium-sensing receptor monomers are important for its normal function. Proc. Natl. Acad. Sci. USA 1999, 96, 2834-2839.

42. Maggio, R.; Barbier, P.; Colelli, A.; Salvadori, F.; Demontis, G.; Corsini, G.U. G protein-linked receptors: Pharmacological evidence for the formation of heterodimers. J. Pharmacol. Exp. Ther. 1999, 291, 251-257.

43. Scarselli, M.; Novi, F.; Schallmach, E.; Lin, R.; Baragli, A.; Colzi, A.; Griffon, N.; Corsini, G.U.; Sokoloff, P.; Levenson, R.; et al. D2/D3 dopamine receptor heterodimers exhibit unique functional properties. J. Biol. Chem. 2001, 276, 30308-30314.

44. White, J.H.; Wise, A.; Main, M.J.; Green, A.; Fraser, N.J.; Disney, G.H.; Barnes, A.A.; Emson, P.; Foord, S.M.; Marshall, F.H. Heterodimerization is required for the formation of a functional GABA(B) receptor. Nature 1998, 396, 679-682.

45. Stanasila, L.; Perez, J.B.; Vogel, H.; Cotecchia, S. Oligomerization of the alpha 1a- and alpha 1b-adrenergic receptor subtypes. Potential implications in receptor internalization. J. Biol. Chem. 2003, 278, 40239-40251.

46. Angers, S.; Salahpour, A.; Joly, E.; Hilairet, S.; Chelsky, D.; Dennis, M.; Bouvier, M. Detection of beta 2-adrenergic receptor dimerization in living cells using bioluminescence resonance energy transfer (BRET). Proc. Natl. Acad. Sci. USA 2000, 97, 3684-3689.

47. Lee, S.P.; O’Dowd, B.F.; Ng, G.Y.; Varghese, G.; Akil, H.; Mansour, A.; Nguyen, T.; George, S.R. Inhibition of cell surface expression by mutant receptors demonstrates that D2 dopamine receptors exist as oligomers in the cell. Mol. Pharmacol. 2000, 58, 120-128.

48. George, S.R.; Lee, S.P.; Varghese, G.; Zeman, P.R.; Seeman, P.; Ng, G.Y.; O’Dowd, B.F. A transmembrane domain-derived peptide inhibits D1 dopamine receptor function without affecting receptor oligomerization. J. Biol. Chem. 1998, 273, 30244-30248.

49. George, S.R.; Fan, T.; Xie, Z.; Tse, R.; Tam, V.; Varghese, G.; O’Dowd, B.F. Oligomerization of mu- and delta-opioid receptors. Generation of novel functional properties. J. Biol. Chem. 2000, 275, 26128-26135.

50. Gomes, I.; Jordan, B.A.; Gupta, A.; Trapaidze, N.; Nagy, V.; Devi, L.A. Heterodimerization of mu and delta opioid receptors: A role in opiate synergy. J. Neurosci. 2000, 20, RC110.

51. Trettel, F.; di Bartolomeo, S.; Lauro, C.; Catalano, M.; Ciotti, M.T.; Limatola, C. Ligand-independent CXCR2 dimerization. J. Biol. Chem. 2003, 278, 40980-40988.

52. Pfeiffer, M.; Koch, T.; Schroder, H.; Klutzny, M.; Kirscht, S.; Kreienkamp, H.J.; Hollt, V.; Schulz, S. Homo- and heterodimerization of somatostatin receptor subtypes. Inactivation of SST(3) receptor function by heterodimerization with SST(2A). J. Biol. Chem. 2001, 276, 14027-14036.

53. Pfeiffer, M.; Koch, T.; Schroder, H.; Laugsch, M.; Hollt, V.; Schulz, S. Heterodimerization of somatostatin and opioid receptors cross-modulates phosphorylation, internalization, and desensitization. J. Biol. Chem. 2002, 277, 19762-19772.

54. Rozenfeld, R.; Gupta, A.; Gagnidze, K.; Lim, M.P.; Gomes, I.; Lee-Ramos, D.; Nieto, N.; Devi, L.A. AT1R-CBR heteromerization reveals a new mechanism for the pathogenic properties of angiotensin II. EMBO J. 2011, 30, 2350-2363. 
55. Jordan, B.A.; Trapaidze, N.; Gomes, I.; Nivarthi, R.; Devi, L.A. Oligomerization of opioid receptors with beta 2 -adrenergic receptors: A role in trafficking and mitogen-activated protein kinase activation. Proc. Natl. Acad. Sci. USA 2001, 98, 343-348.

56. Jones, K.A.; Borowsky, B.; Tamm, J.A.; Craig, D.A.; Durkin, M.M.; Dai, M.; Yao, W.J.; Johnson, M.; Gunwaldsen, C.; Huang, L.Y.; et al. GABA(B) receptors function as a heteromeric assembly of the subunits GABA(B)R1 and GABA(B)R2. Nature 1998, 396, 674-679.

57. Kaupmann, K.; Malitschek, B.; Schuler, V.; Heid, J.; Froestl, W.; Beck, P.; Mosbacher, J.; Bischoff, S.; Kulik, A.; Shigemoto, R.; et al. GABA(B)-receptor subtypes assemble into functional heteromeric complexes. Nature 1998, 396, 683-687.

58. Gama, L.; Wilt, S.G.; Breitwieser, G.E. Heterodimerization of calcium sensing receptors with metabotropic glutamate receptors in neurons. J. Biol. Chem. 2001, 276, 39053-39059.

59. Latif, R.; Graves, P.; Davies, T.F. Ligand-dependent inhibition of oligomerization at the human thyrotropin receptor. J. Biol. Chem. 2002, 277, 45059-45067.

60. Dinger, M.C.; Bader, J.E.; Kobor, A.D.; Kretzschmar, A.K.; Beck-Sickinger, A.G. Homodimerization of neuropeptide $\mathrm{Y}$ receptors investigated by fluorescence resonance energy transfer in living cells. J. Biol. Chem. 2003, 278, 10562-10571.

61. Wurch, T.; Matsumoto, A.; Pauwels, P.J. Agonist-independent and -dependent oligomerization of dopamine $\mathrm{D}(2)$ receptors by fusion to fluorescent proteins. FEBS Lett. 2001, 507, 109-113.

62. Mellado, M.; Rodriguez-Frade, J.M.; Vila-Coro, A.J.; Fernandez, S.; Martin de Ana, A.; Jones, D.R.; Toran, J.L.; Martinez, A.C. Chemokine receptor homo- or heterodimerization activates distinct signaling pathways. EMBO J. 2001, 20, 2497-2507.

63. Duran-Prado, M.; Bucharles, C.; Gonzalez, B.J.; Vazquez-Martinez, R.; Martinez-Fuentes, A.J.; Garcia-Navarro, S.; Rhodes, S.J.; Vaudry, H.; Malagon, M.M.; Castano, J.P. Porcine somatostatin receptor 2 displays typical pharmacological SST2 features but unique dynamics of homodimerization and internalization. Endocrinology 2007, 148, 411-421.

64. Duran-Prado, M.; Saveanu, A.; Luque, R.M.; Gahete, M.D.; Gracia-Navarro, F.; Jaquet, P.; Dufour, H.; Malagon, M.M.; Culler, M.D.; Barlier, A.; et al. A potential inhibitory role for the new truncated variant of somatostatin receptor 5, sst5TMD4, in pituitary adenomas poorly responsive to somatostatin analogs. J. Clin. Endocrinol. Metab. 2011, 95, 2497-2502.

65. Horvat, R.D.; Roess, D.A.; Nelson, S.E.; Barisas, B.G.; Clay, C.M. Binding of agonist but not antagonist leads to fluorescence resonance energy transfer between intrinsically fluorescent gonadotropin-releasing hormone receptors. Mol. Endocrinol. 2001, 15, 695-703.

66. Cornea, A.; Janovick, J.A.; Maya-Nunez, G.; Conn, P.M. Gonadotropin-releasing hormone receptor microaggregation. Rate monitored by fluorescence resonance energy transfer. J. Biol. Chem. 2001, 276, 2153-2158.

67. Somvanshi, R.K.; Chaudhari, N.; Yang, B.; Sastry, B.R.; Kumar, U. Somatostatin receptor-4 and $\mu$-opioid receptor interaction modulates receptor coupling, signaling and excitatory postsynaptic currents. In 2011 Neuroscience meeting, Washington, DC, USA, 12-16 November 2011.

68. Lavoie, C.; Mercier, J.F.; Salahpour, A.; Umapathy, D.; Breit, A.; Villeneuve, L.R.; Zhu, W.Z.; Xiao, R.P.; Lakatta, E.G.; Bouvier, M.; et al. Beta 1/beta 2-adrenergic receptor heterodimerization regulates beta 2-adrenergic receptor internalization and ERK signaling efficacy. J. Biol. Chem. 2002, 277, 35402-35410. 
69. Hanyaloglu, A.C.; Seeber, R.M.; Kohout, T.A.; Lefkowitz, R.J.; Eidne, K.A. Homo- and hetero-oligomerization of thyrotropin-releasing hormone (TRH) receptor subtypes. Differential regulation of beta-arrestins 1 and 2. J. Biol. Chem. 2002, 277, 50422-50430.

70. Gomes, I.; Filipovska, J.; Jordan, B.A.; Devi, L.A. Oligomerization of opioid receptors. Methods 2002, 27, 358-365.

71. Issafras, H.; Angers, S.; Bulenger, S.; Blanpain, C.; Parmentier, M.; Labbe-Jullie, C.; Bouvier, M.; Marullo, S. Constitutive agonist-independent CCR5 oligomerization and antibody-mediated clustering occurring at physiological levels of receptors. J. Biol. Chem. 2002, 277, 34666-34673.

72. Yoshioka, K.; Saitoh, O.; Nakata, H. Agonist-promoted heteromeric oligomerization between adenosine A(1) and P2Y(1) receptors in living cells. FEBS Lett. 2002, 523, 147-151.

73. Kamiya, T.; Saitoh, O.; Yoshioka, K.; Nakata, H. Oligomerization of adenosine A2A and dopamine D2 receptors in living cells. Biochem. Biophys. Res. Commun. 2003, 306, 544-549.

74. McVey, M.; Ramsay, D.; Kellett, E.; Rees, S.; Wilson, S.; Pope, A.J.; Milligan, G. Monitoring receptor oligomerization using time-resolved fluorescence resonance energy transfer and bioluminescence resonance energy transfer. The human delta-opioid receptor displays constitutive oligomerization at the cell surface, which is not regulated by receptor occupancy. J. Biol. Chem. 2001, 276, 14092-14099.

75. van Rijn, R.M.; Chazot, P.L.; Shenton, F.C.; Sansuk, K.; Bakker, R.A.; Leurs, R. Oligomerization of recombinant and endogenously expressed human histamine $\mathrm{H}(4)$ receptors. Mol. Pharmacol. 2006, 70, 604-615.

76. Maurel, D.; Comps-Agrar, L.; Brock, C.; Rives, M.L.; Bourrier, E.; Ayoub, M.A.; Bazin, H.; Tinel, N.; Durroux, T.; Prezeau, L.; et al. Cell-surface protein-protein interaction analysis with time-resolved FRET and snap-tag technologies: Application to GPCR oligomerization. Nat. Methods 2008, 5, 561-567.

77. Bourne, H.R.; Sanders, D.A.; McCormick, F. The gtpase superfamily: Conserved structure and molecular mechanism. Nature 1991, 349, 117-127.

78. Hamm, H.E. The many faces of G protein signaling. J. Biol. Chem. 1998, 273, 669-672.

79. Neves, S.R.; Ram, P.T.; Iyengar, R. G protein pathways. Science 2002, 296, 1636-1639.

80. Rodbell, M. The role of hormone receptors and GTP-regulatory proteins in membrane transduction. Nature 1980, 284, 17-22.

81. Wettschureck, N.; Offermanns, S. Mammalian G proteins and their cell type specific functions. Physiol. Rev. 2005, 85, 1159-1204.

82. Murphy, P.M. International union of pharmacology. XXX. Update on chemokine receptor nomenclature. Pharmacol. Rev. 2002, 54, 227-229.

83. Law, P.Y.; Wong, Y.H.; Loh, H.H. Molecular mechanisms and regulation of opioid receptor signaling. Annu. Rev. Pharmacol. Toxicol. 2000, 40, 389-430.

84. Patel, Y.C. Somatostatin and its receptor family. Front. Neuroendocrinol. 1999, 20, 157-198.

85. Michel, M.C.; Beck-Sickinger, A.; Cox, H.; Doods, H.N.; Herzog, H.; Larhammar, D.; Quirion, R.; Schwartz, T.; Westfall, T. XVI. International union of pharmacology recommendations for the nomenclature of neuropeptide Y, peptide YY, and pancreatic polypeptide receptors. Pharmacol. Rev. 1998, 50, 143-150. 
86. Dubocovich, M.L.; Masana, M.I.; Benloucif, S. Molecular pharmacology and function of melatonin receptor subtypes. Adv. Exp. Med. Biol. 1999, 460, 181-190.

87. Alexander, S.P.; Mathie, A.; Peters, J.A. Guide to receptors and channels (GRAC), 5th edition. Br. J. Pharmacol. 2011, 164, S1-S324.

88. Contos, J.J.; Ishii, I.; Fukushima, N.; Kingsbury, M.A.; Ye, X.; Kawamura, S.; Brown, J.H.; Chun, J. Characterization of $l p a_{2}(E d g 4)$ and $l p a_{1} / l p a_{2}$ (Edg2/Edg4) lysophosphatidic acid receptor knockout mice: Signaling deficits without obvious phenotypic abnormality attributable to lpa $_{2}$. Mol. Cell. Biol. 2002, 22, 6921-6929.

89. Hoyer, D.; Clarke, D.E.; Fozard, J.R.; Hartig, P.R.; Martin, G.R.; Mylecharane, E.J.; Saxena, P.R.; Humphrey, P.P. International union of pharmacology classification of receptors for 5-hydroxytryptamine (serotonin). Pharmacol. Rev. 1994, 46, 157-203.

90. Wess, J. Muscarinic acetylcholine receptor knockout mice: Novel phenotypes and clinical implications. Annu. Rev. Pharmacol. Toxicol. 2004, 44, 423-450.

91. Caulfield, M.P. Muscarinic receptors-Characterization, coupling and function. Pharmacol. Ther. 1993, 58, 319-379.

92. Le, Y.; Murphy, P.M.; Wang, J.M. Formyl-peptide receptors revisited. Trends Immunol. 2002, 23, 541-548.

93. Xiao, R.P.; Avdonin, P.; Zhou, Y.Y.; Cheng, H.; Akhter, S.A.; Eschenhagen, T.; Lefkowitz, R.J.; Koch, W.J.; Lakatta, E.G. Coupling of beta2-adrenoceptor to $\mathrm{G}_{\mathrm{i}}$ proteins and its physiological relevance in murine cardiac myocytes. Circ. Res. 1999, 84, 43-52.

94. Hata, A.N.; Breyer, R.M. Pharmacology and signaling of prostaglandin receptors: Multiple roles in inflammation and immune modulation. Pharmacol. Ther. 2004, 103, 147-166.

95. Kim, I.S.; Kim, E.R.; Nam, H.J.; Chin, M.O.; Moon, Y.H.; Oh, M.R.; Yeo, U.C.; Song, S.M.; Kim, J.S.; Uhm, M.R.; et al. Activating mutation of GS $\alpha$ in mccune-albright syndrome causes skin pigmentation by tyrosinase gene activation on affected melanocytes. Horm. Res. 1999, 52, 235-240.

96. Wikberg, J.E. Melanocortin receptors: Perspectives for novel drugs. Eur. J. Pharmacol. 1999, 375, 295-310.

97. Bathgate, R.A.; Samuel, C.S.; Burazin, T.C.; Gundlach, A.L.; Tregear, G.W. Relaxin: New peptides, receptors and novel actions. Trends Endocrinol. Metab. 2003, 14, 207-213.

98. Fredholm, B.B.; AP, I.J.; Jacobson, K.A.; Klotz, K.N.; Linden, J. International union of pharmacology. XXV. Nomenclature and classification of adenosine receptors. Pharmacol. Rev. 2001, 53, 527-552.

99. Hermosilla, R. Vasopressin/Oxytocin; Springer: Berlin, Germany, 2004; pp. 957-961.

100. Millar, R.P.; Lu, Z.L.; Pawson, A.J.; Flanagan, C.A.; Morgan, K.; Maudsley, S.R. Gonadotropin-releasing hormone receptors. Endocr. Rev. 2004, 25, 235-275.

101. Fredholm, B.B.; Abbracchio, M.P.; Burnstock, G.; Dubyak, G.R.; Harden, T.K.; Jacobson, K.A.; Schwabe, U.; Williams, M. Towards a revised nomenclature for P1 and P2 receptors. Trends Pharmacol. Sci. 1997, 18, 79-82.

102. Fredholm, B.B.; Abbracchio, M.P.; Burnstock, G.; Daly, J.W.; Harden, T.K.; Jacobson, K.A.; Leff, P.; Williams, M. Nomenclature and classification of purinoceptors. Pharmacol. Rev. 1994, $46,143-156$. 
103. Leeb-Lundberg, L.M.; Marceau, F.; Muller-Esterl, W.; Pettibone, D.J.; Zuraw, B.L. International union of pharmacology. XLV. Classification of the kinin receptor family: From molecular mechanisms to pathophysiological consequences. Pharmacol. Rev. 2005, 57, 27-77.

104. Shulkes, A.; Baldwin, G.S. Biology of gut cholecystokinin and gastrin receptors. Clin. Exp. Pharmacol. Physiol. 1997, 24, 209-216.

105. Ohki-Hamazaki, H. Neuromedin B. Prog. Neurobiol. 2000, 62, 297-312.

106. Vincent, J.P.; Mazella, J.; Kitabgi, P. Neurotensin and neurotensin receptors. Trends Pharmacol. Sci. 1999, 20, 302-309.

107. Vassart, G.; Pardo, L.; Costagliola, S. A molecular dissection of the glycoprotein hormone receptors. Trends Biochem. Sci. 2004, 29, 119-126.

108. Martin, N.P.; Whalen, E.J.; Zamah, M.A.; Pierce, K.L.; Lefkowitz, R.J. PKA-mediated phosphorylation of the beta1-adrenergic receptor promotes $G_{s} / G_{i}$ switching. Cell. Signal. 2004, 16, 1397-1403.

109. Zhu, W.Z.; Zheng, M.; Koch, W.J.; Lefkowitz, R.J.; Kobilka, B.K.; Xiao, R.P. Dual modulation of cell survival and cell death by beta(2)-adrenergic signaling in adult mouse cardiac myocytes. Proc. Natl. Acad. Sci. USA 2001, 98, 1607-1612.

110. Walker, M.W.; Smith, K.E. Galanin Receptors; Springer: Berlin, Germany, 2004; pp. 378-383.

111. Davenport, A.P. International union of pharmacology. XXIX. Update on endothelin receptor nomenclature. Pharmacol. Rev. 2002, 54, 219-226.

112. Poyner, D.R.; Sexton, P.M.; Marshall, I.; Smith, D.M.; Quirion, R.; Born, W.; Muff, R.; Fischer, J.A.; Foord, S.M. International union of pharmacology. XXXII. The mammalian calcitonin gene-related peptides, adrenomedullin, amylin, and calcitonin receptors. Pharmacol. Rev. 2002, 54, 233-246.

113. Gardella, T.J.; Juppner, H. Molecular properties of the PTH/PTHrP receptor. Trends. Endocrinol. Metab. 2001, 12, 210-217.

114. Ishii, I.; Fukushima, N.; Ye, X.; Chun, J. Lysophospholipid receptors: Signaling and biology. Annu. Rev. Biochem. 2004, 73, 321-354.

115. Meyer zu Heringdorf, D.; Jakobs, K.H. Lysophospholipid receptors: Signalling, pharmacology and regulation by lysophospholipid metabolism. Biochim. Biophys. Acta 2007, 1768, 923-940.

116. Billington, C.K.; Penn, R.B. Signaling and regulation of $\mathrm{G}$ protein-coupled receptors in airway smooth muscle. Respir. Res. 2003, 4, 2.

117. Horn, F.; van der Wenden, E.M.; Oliveira, L.; AP, I.J.; Vriend, G. Receptors coupling to G proteins: Is there a signal behind the sequence? Proteins 2000, 41, 448-459.

118. Kroeze, W.K.; Sheffler, D.J.; Roth, B.L. G-protein-coupled receptors at a glance. J. Cell Sci. 2003, 116, 4867-4869.

119. Brodde, O.E. Beta 1- and beta 2-adrenoceptors in the human heart: Properties, function, and alterations in chronic heart failure. Pharmacol. Rev. 1991, 43, 203-242.

120. Brodde, O.E. Beta-adrenoceptors in cardiac disease. Pharmacol. Ther. 1993, 60, 405-430.

121. Rockman, H.A.; Koch, W.J.; Lefkowitz, R.J. Seven-transmembrane-spanning receptors and heart function. Nature 2002, 415, 206-212. 
122. Cruciani, R.A.; Dvorkin, B.; Morris, S.A.; Crain, S.M.; Makman, M.H. Direct coupling of opioid receptors to both stimulatory and inhibitory guanine nucleotide-binding proteins in F-11 neuroblastoma-sensory neuron hybrid cells. Proc. Natl. Acad. Sci. USA 1993, 90, 3019-3023.

123. Ramirez, J.L.; Gracia-Navarro, F.; Garcia-Navarro, S.; Torronteras, R.; Malagon, M.M.; Castano, J.P. Somatostatin stimulates GH secretion in two porcine somatotrope subpopulations through a camp-dependent pathway. Endocrinology 2002, 143, 889-897.

124. Ben-Shlomo, A.; Melmed, S. Pituitary somatostatin receptor signaling. Trends Endocrinol. Metab. 2010, 21, 123-133.

125. Pei, L.; Li, S.; Wang, M.; Diwan, M.; Anisman, H.; Fletcher, P.J.; Nobrega, J.N.; Liu, F. Uncoupling the dopamine D1-D2 receptor complex exerts antidepressant-like effects. Nat. Med. 2010, 16, 1393-1395.

126. Protein lounge. Available online: http://www.proteinlounge.com/ (accessed on 18 April 2012).

127. Fraser, C.M.; Venter, J.C. The size of the mammalian lung beta 2-adrenergic receptor as determined by target size analysis and immunoaffinity chromatography. Biochem. Biophys. Res. Commun. 1982, 109, 21-29.

128. Paglin, S.; Jamieson, J.D. Covalent crosslinking of angiotensin II to its binding sites in rat adrenal membranes. Proc. Natl. Acad. Sci. USA 1982, 79, 3739-3743.

129. Hebert, T.E.; Bouvier, M. Structural and functional aspects of G protein-coupled receptor oligomerization. Biochem. Cell Biol. 1998, 76, 1-11.

130. Marshall, F.H.; Jones, K.A.; Kaupmann, K.; Bettler, B. Gabab receptors-The first 7TM heterodimers. Trends Pharmacol. Sci. 1999, 20, 396-399.

131. Mohler, H.; Fritschy, J.M. Gabab receptors make it to the top-As dimers. Trends Pharmacol. Sci. 1999, 20, 87-89.

132. Zhao, G.Q.; Zhang, Y.; Hoon, M.A.; Chandrashekar, J.; Erlenbach, I.; Ryba, N.J.; Zuker, C.S. The receptors for mammalian sweet and umami taste. Cell 2003, 115, 255-266.

133. Jordan, B.A.; Devi, L.A. G-protein-coupled receptor heterodimerization modulates receptor function. Nature 1999, 399, 697-700.

134. Cvejic, S.; Devi, L.A. Dimerization of the delta opioid receptor: Implication for a role in receptor internalization. J. Biol. Chem. 1997, 272, 26959-26964.

135. Videau, C.; Hochgeschwender, U.; Kreienkamp, H.J.; Brennan, M.B.; Viollet, C.; Richter, D.; Epelbaum, J. Characterisation of [125I]-Tyr ${ }^{0} \mathrm{dtrp}^{8}$-somatostatin binding in sst1- to sst4- and SRIF-gene-invalidated mouse brain. Naunyn Schmiedebergs Arch. Pharmacol. 2003, 367, 562-571.

136. Viollet, C.; Lepousez, G.; Loudes, C.; Videau, C.; Simon, A.; Epelbaum, J. Somatostatinergic systems in brain: Networks and functions. Mol. Cell. Endocrinol. 2008, 286, 75-87.

137. Olias, G.; Viollet, C.; Kusserow, H.; Epelbaum, J.; Meyerhof, W. Regulation and function of somatostatin receptors. J. Neurochem. 2004, 89, 1057-1091.

138. Ramirez, J.L.; Mouchantaf, R.; Kumar, U.; Otero Corchon, V.; Rubinstein, M.; Low, M.J.; Patel, Y.C. Brain somatostatin receptors are up-regulated in somatostatin-deficient mice. Mol. Endocrinol. 2002, 16, 1951-1963.

139. Tallent, M.K.; Siggins, G.R. Somatostatin acts in CA1 and CA3 to reduce hippocampal epileptiform activity. J. Neurophysiol. 1999, 81, 1626-1635. 
140. Reubi, J.C.; Waser, B.; Schaer, J.C.; Laissue, J.A. Somatostatin receptor sst1-sst5 expression in normal and neoplastic human tissues using receptor autoradiography with subtype-selective ligands. Eur. J. Nucl. Med. 2001, 28, 836-846.

141. Cervia, D.; Nunn, C.; Fehlmann, D.; Langenegger, D.; Schuepbach, E.; Hoyer, D. Pharmacological characterisation of native somatostatin receptors in AtT-20 mouse tumour corticotrophs. Br. J. Pharmacol. 2003, 139, 109-121.

142. Patel, R.C.; Kumar, U.; Lamb, D.C.; Eid, J.S.; Rocheville, M.; Grant, M.; Rani, A.; Hazlett, T.; Patel, S.C.; Gratton, E.; et al. Ligand binding to somatostatin receptors induces receptor-specific oligomer formation in live cells. Proc. Natl. Acad. Sci. USA 2002, 99, 3294-3299.

143. Viollet, C.; Bodenant, C.; Prunotto, C.; Roosterman, D.; Schaefer, J.; Meyerhof, W.; Epelbaum, J.; Vaudry, H.; Leroux, P. Differential expression of multiple somatostatin receptors in the rat cerebellum during development. J. Neurochem. 1997, 68, 2263-2272.

144. Gines, S.; Hillion, J.; Torvinen, M.; Le Crom, S.; Casado, V.; Canela, E.I.; Rondin, S.; Lew, J.Y.; Watson, S.; Zoli, M.; et al. Dopamine D1 and adenosine A1 receptors form functionally interacting heteromeric complexes. Proc. Natl. Acad. Sci. USA 2000, 97, 8606-8611.

145. Kearn, C.S.; Blake-Palmer, K.; Daniel, E.; Mackie, K.; Glass, M. Concurrent stimulation of cannabinoid CB1 and dopamine D2 receptors enhances heterodimer formation: A mechanism for receptor cross-talk? Mol. Pharmacol. 2005, 67, 1697-1704.

146. Pello, O.M.; Martinez-Munoz, L.; Parrillas, V.; Serrano, A.; Rodriguez-Frade, J.M.; Toro, M.J.; Lucas, P.; Monterrubio, M.; Martinez, A.C.; Mellado, M. Ligand stabilization of CXCR4/ delta-opioid receptor heterodimers reveals a mechanism for immune response regulation. Eur. $J$. Immunol. 2008, 38, 537-549.

147. Rodriguez-Frade, J.M.; del Real, G.; Serrano, A.; Hernanz-Falcon, P.; Soriano, S.F.; Vila-Coro, A.J.; de Ana, A.M.; Lucas, P.; Prieto, I.; Martinez, A.C.; et al. Blocking HIV-1 infection via CCR5 and CXCR4 receptors by acting in trans on the CCR2 chemokine receptor. EMBO J. 2004, 23, 66-76.

148. McGraw, D.W.; Mihlbachler, K.A.; Schwarb, M.R.; Rahman, F.F.; Small, K.M.; Almoosa, K.F.; Liggett, S.B. Airway smooth muscle prostaglandin-EP1 receptors directly modulate beta2-adrenergic receptors within a unique heterodimeric complex. J. Clin. Invest. 2006, 116, 1400-1409.

149. Vila-Coro, A.J.; Rodriguez-Frade, J.M.; Martin De Ana, A.; Moreno-Ortiz, M.C.; Martinez, A.C.; Mellado, M. The chemokine SDF-1alpha triggers CXCR4 receptor dimerization and activates the JAK/STAT pathway. FASEB J. 1999, 13, 1699-1710.

150. Berglund, M.M.; Schober, D.A.; Esterman, M.A.; Gehlert, D.R. Neuropeptide Y Y4 receptor homodimers dissociate upon agonist stimulation. J. Pharmacol. Exp. Ther. 2003, 307, 1120-1126.

151. Latif, R.; Graves, P.; Davies, T.F. Oligomerization of the human thyrotropin receptor: Fluorescent protein-tagged hTSHR reveals post-translational complexes. J. Biol. Chem. 2001, 276, 45217-45224.

152. Ayoub, M.A.; Couturier, C.; Lucas-Meunier, E.; Angers, S.; Fossier, P.; Bouvier, M.; Jockers, R. Monitoring of ligand-independent dimerization and ligand-induced conformational changes of melatonin receptors in living cells by bioluminescence resonance energy transfer. J. Biol. Chem. 2002, 277, 21522-21528. 
153. Perron, A.; Chen, Z.G.; Gingras, D.; Dupre, D.J.; Stankova, J.; Rola-Pleszczynski, M. Agonist-independent desensitization and internalization of the human platelet-activating factor receptor by coumermycin-gyrase B-induced dimerization. J. Biol. Chem. 2003, 278, 27956-27965.

154. Song, G.J.; Hinkle, P.M. Regulated dimerization of the thyrotropin-releasing hormone receptor affects receptor trafficking but not signaling. Mol. Endocrinol. 2005, 19, 2859-2870.

155. Margeta-Mitrovic, M.; Jan, Y.N.; Jan, L.Y. Function of GB1 and GB2 subunits in G protein coupling of GABA(B) receptors. Proc. Natl. Acad. Sci. USA 2001, 98, 14649-14654.

156. Green, S.A.; Turki, J.; Innis, M.; Liggett, S.B. Amino-terminal polymorphisms of the human beta 2-adrenergic receptor impart distinct agonist-promoted regulatory properties. Biochemistry 1994, 33, 9414-9419.

157. Lappalainen, J.; Zhang, L.; Dean, M.; Oz, M.; Ozaki, N.; Yu, D.H.; Virkkunen, M.; Weight, F.; Linnoila, M.; Goldman, D. Identification, expression, and pharmacology of a Cys23-Ser23 substitution in the human 5-HT2c receptor gene (HTR2C). Genomics 1995, 27, 274-279.

158. Bond, C.; LaForge, K.S.; Tian, M.; Melia, D.; Zhang, S.; Borg, L.; Gong, J.; Schluger, J.; Strong, J.A.; Leal, S.M.; et al. Single-nucleotide polymorphism in the human mu opioid receptor gene alters beta-endorphin binding and activity: Possible implications for opiate addiction. Proc. Natl. Acad. Sci. USA 1998, 95, 9608-9613.

159. Rotondo, A.; Nielsen, D.A.; Nakhai, B.; Hulihan-Giblin, B.; Bolos, A.; Goldman, D. Agonist-promoted down-regulation and functional desensitization in two naturally occurring variants of the human serotonin 1A receptor. Neuropsychopharmacology 1997, 17, 18-26.

160. Kunishima, N.; Shimada, Y.; Tsuji, Y.; Sato, T.; Yamamoto, M.; Kumasaka, T.; Nakanishi, S.; Jingami, H.; Morikawa, K. Structural basis of glutamate recognition by a dimeric metabotropic glutamate receptor. Nature 2000, 407, 971-977.

161. Bai, M.; Trivedi, S.; Brown, E.M. Dimerization of the extracellular calcium-sensing receptor (CaR) on the cell surface of CaR-transfected HEK293 cells. J. Biol. Chem. 1998, 273, 23605-23610.

162. AbdAlla, S.; Zaki, E.; Lother, H.; Quitterer, U. Involvement of the amino terminus of the B(2) receptor in agonist-induced receptor dimerization. J. Biol. Chem. 1999, 274, 26079-26084.

163. Zhang, Z.; Sun, S.; Quinn, S.J.; Brown, E.M.; Bai, M. The extracellular calcium-sensing receptor dimerizes through multiple types of intermolecular interactions. J. Biol. Chem. 2001, 276, 5316-5322.

164. Ray, K.; Hauschild, B.C. Cys-140 is critical for metabotropic glutamate receptor-1 dimerization. J. Biol. Chem. 2000, 275, 34245-34251.

165. Kuner, R.; Kohr, G.; Grunewald, S.; Eisenhardt, G.; Bach, A.; Kornau, H.C. Role of heteromer formation in GABAB receptor function. Science 1999, 283, 74-77.

166. Rana, B.K.; Shiina, T.; Insel, P.A. Genetic variations and polymorphisms of g protein-coupled receptors: Functional and therapeutic implications. Annu. Rev. Pharmacol. Toxicol. 2001, 41, 593-624.

167. Liu, I.S.; Seeman, P.; Sanyal, S.; Ulpian, C.; Rodgers-Johnson, P.E.; Serjeant, G.R.; van Tol, H.H. Dopamine D4 receptor variant in africans, D4valine194glycine, is insensitive to dopamine and clozapine: Report of a homozygous individual. Am. J. Med. Genet. 1996, 61, 277-282. 
168. Kotlar, T.J.; Young, R.H.; Albanese, C.; Crowley, W.F., Jr.; Scully, R.E.; Jameson, J.L. A mutation in the follicle-stimulating hormone receptor occurs frequently in human ovarian sex cord tumors. J. Clin. Endocrinol. Metab. 1997, 82, 1020-1026.

169. Fotiadis, D.; Liang, Y.; Filipek, S.; Saperstein, D.A.; Engel, A.; Palczewski, K. Atomic-force microscopy: Rhodopsin dimers in native disc membranes. Nature 2003, 421, 127-128.

170. Carrillo, J.J.; Pediani, J.; Milligan, G. Dimers of class a G protein-coupled receptors function via agonist-mediated trans-activation of associated g proteins. J. Biol. Chem. 2003, 278, 42578-42587.

171. Yoshioka, K.; Saitoh, O.; Nakata, H. Heteromeric association creates a P2Y-like adenosine receptor. Proc. Natl. Acad. Sci. USA 2001, 98, 7617-7622.

172. AbdAlla, S.; Lother, H.; Quitterer, U. AT1-receptor heterodimers show enhanced G-protein activation and altered receptor sequestration. Nature 2000, 407, 94-98.

173. Mellado, M.; Rodriguez-Frade, J.M.; Vila-Coro, A.J.; de Ana, A.M.; Martinez, A.C. Chemokine control of HIV-1 infection. Nature 1999, 400, 723-724.

174. Lee, B.; Doranz, B.J.; Rana, S.; Yi, Y.; Mellado, M.; Frade, J.M.; Martinez, A.C.; O’Brien, S.J.; Dean, M.; Collman, R.G.; et al. Influence of the CCR2-V64I polymorphism on human immunodeficiency virus type 1 coreceptor activity and on chemokine receptor function of CCR2b, CCR3, CCR5, and CXCR4. J. Virol. 1998, 72, 7450-7458.

175. Barki-Harrington, L.; Luttrell, L.M.; Rockman, H.A. Dual inhibition of beta-adrenergic and angiotensin II receptors by a single antagonist: A functional role for receptor-receptor interaction in vivo. Circulation 2003, 108, 1611-1618.

176. Barki-Harrington, L.; Bookout, A.L.; Wang, G.; Lamb, M.E.; Leeb-Lundberg, L.M.; Daaka, Y. Requirement for direct cross-talk between B1 and B2 kinin receptors for the proliferation of androgen-insensitive prostate cancer PC3 cells. Biochem. J. 2003, 371, 581-587.

177. AbdAlla, S.; Lother, H.; El Massiery, A.; Quitterer, U. Increased AT(1) receptor heterodimers in preeclampsia mediate enhanced angiotensin II responsiveness. Nat. Med. 2001, 7, 1003-1009.

178. Hansen, J.L.; Hansen, J.T.; Speerschneider, T.; Lyngso, C.; Erikstrup, N.; Burstein, E.S.; Weiner, D.M.; Walther, T.; Makita, N.; Iiri, T.; et al. Lack of evidence for AT1R/B2R heterodimerization in COS-7, HEK293, and NIH3T3 cells: How common is the AT1R/B2R heterodimer? J. Biol. Chem. 2009, 284, 1831-1839.

179. Quitterer, U.; Lother, H.; Abdalla, S. AT1 receptor heterodimers and angiotensin II responsiveness in preeclampsia. Semin. Nephrol. 2004, 24, 115-119.

180. AbdAlla, S.; Abdel-Baset, A.; Lother, H.; El Massiery, A.; Quitterer, U. Mesangial AT1/B2 receptor heterodimers contribute to angiotensin II hyperresponsiveness in experimental hypertension. J. Mol. Neurosci. 2005, 26, 185-192.

181. Gonzalez-Maeso, J.; Ang, R.L.; Yuen, T.; Chan, P.; Weisstaub, N.V.; Lopez-Gimenez, J.F.; Zhou, M.; Okawa, Y.; Callado, L.F.; Milligan, G.; et al. Identification of a serotonin/glutamate receptor complex implicated in psychosis. Nature 2008, 452, 93-97.

182. Sealfon, S.C.; Gonzalez-Maeso, J. Receptor pair for schizophrenia. Pediatr. Res. 2008, 64, 1.

183. Dalrymple, M.B.; Pfleger, K.D.; Eidne, K.A. G protein-coupled receptor dimers: Functional consequences, disease states and drug targets. Pharmacol. Ther. 2008, 118, 359-371.

184. Blandini, F. Adenosine receptors and 1-dopa-induced dyskinesia in Parkinson's disease: Potential targets for a new therapeutic approach. Exp. Neurol. 2003, 184, 556-560. 
185. Fuxe, K.; Ferre, S.; Canals, M.; Torvinen, M.; Terasmaa, A.; Marcellino, D.; Goldberg, S.R.; Staines, W.; Jacobsen, K.X.; Lluis, C.; et al. Adenosine A2A and dopamine D2 heteromeric receptor complexes and their function. J. Mol. Neurosci. 2005, 26, 209-220.

186. Fuxe, K.; Marcellino, D.; Genedani, S.; Agnati, L. Adenosine A2A receptors, dopamine D2 receptors and their interactions in Parkinson's disease. Mov. Disord. 2007, 22, 1990-2017.

187. Kanda, T.; Jackson, M.J.; Smith, L.A.; Pearce, R.K.; Nakamura, J.; Kase, H.; Kuwana, Y.; Jenner, P. Adenosine A2A antagonist: A novel antiparkinsonian agent that does not provoke dyskinesia in parkinsonian monkeys. Ann. Neurol. 1998, 43, 507-513.

188. Kumar, U.; Grant, M. Somatostatin and somatostatin receptors. Results Probl. Cell Differ. 2010, 50, 137-184.

189. Kumar, U. Cross-talk and modulation of signaling between somatostatin and growth factor receptors. Endocrine 2011, 40, 168-180.

190. Lamberts, S.W.; de Herder, W.W.; Hofland, L.J. Somatostatin analogs in the diagnosis and treatment of cancer. Trends Endocrinol. Metab. 2002, 13, 451-457.

191. Hofland, L.J. Somatostatin and somatostatin receptors in cushing's disease. Mol. Cell. Endocrinol. 2008, 286, 199-205.

192. Hofland, L.J.; Feelders, R.A.; de Herder, W.W.; Lamberts, S.W. Pituitary tumours: The sst/D2 receptors as molecular targets. Mol. Cell. Endocrinol. 2010, 326, 89-98.

193. Hofland, L.J.; Lamberts, S.W. Somatostatin receptor subtype expression in human tumors. Ann. Oncol. 2001, 12, S31-S36.

194. Gatto, F.; Hofland, L.J. The role of somatostatin and dopamine D2 receptors in endocrine tumors. Endocr. Relat. Cancer 2011, 18, R233-R251.

195. Jaquet, P.; Gunz, G.; Saveanu, A.; Dufour, H.; Taylor, J.; Dong, J.; Kim, S.; Moreau, J.P.; Enjalbert, A.; Culler, M.D. Efficacy of chimeric molecules directed towards multiple somatostatin and dopamine receptors on inhibition of GH and prolactin secretion from GH-secreting pituitary adenomas classified as partially responsive to somatostatin analog therapy. Eur. J. Endocrinol. 2005, 153, 135-141.

196. Saveanu, A.; Gunz, G.; Guillen, S.; Dufour, H.; Culler, M.D.; Jaquet, P. Somatostatin and dopamine-somatostatin multiple ligands directed towards somatostatin and dopamine receptors in pituitary adenomas. Neuroendocrinology 2006, 83, 258-263.

197. Saveanu, A.; Jaquet, P.; Brue, T.; Barlier, A. Relevance of coexpression of somatostatin and dopamine D2 receptors in pituitary adenomas. Mol. Cell. Endocrinol. 2008, 286, 206-213.

198. Saveanu, A.; Lavaque, E.; Gunz, G.; Barlier, A.; Kim, S.; Taylor, J.E.; Culler, M.D.; Enjalbert, A.; Jaquet, P. Demonstration of enhanced potency of a chimeric somatostatin-dopamine molecule, BIM-23A387, in suppressing growth hormone and prolactin secretion from human pituitary somatotroph adenoma cells. J. Clin. Endocrinol. Metab. 2002, 87, 5545-5552.

199. Ben-Shlomo, A.; Melmed, S. Somatostatin agonists for treatment of acromegaly. Mol. Cell. Endocrinol. 2008, 286, 192-198.

200. Plockinger, U.; Albrecht, S.; Mawrin, C.; Saeger, W.; Buchfelder, M.; Petersenn, S.; Schulz, S. Selective loss of somatostatin receptor 2 in octreotide-resistant growth hormone-secreting adenomas. J. Clin. Endocrinol. Metab. 2008, 93, 1203-1210. 
201. Bronstein, M.D. Acromegaly: Molecular expression of somatostatin receptor subtypes and treatment outcome. Front. Horm. Res. 2006, 35, 129-134.

202. Duran-Prado, M.; Gahete, M.D.; Martinez-Fuentes, A.J.; Luque, R.M.; Quintero, A.; Webb, S.M.; Benito-Lopez, P.; Leal, A.; Schulz, S.; Gracia-Navarro, F.; et al. Identification and characterization of two novel truncated but functional isoforms of the somatostatin receptor subtype 5 differentially present in pituitary tumors. J. Clin. Endocrinol. Metab. 2009, 94, 2634-2643.

203. Duran-Prado, M.; Malagon, M.M.; Gracia-Navarro, F.; Castano, J.P. Dimerization of G protein-coupled receptors: New avenues for somatostatin receptor signalling, control and functioning. Mol. Cell. Endocrinol. 2008, 286, 63-68.

204. Duran-Prado, M.; Gahete, M.D.; Hergueta-Redondo, M.; Martinez-Fuentes, A.J.; Cordoba-Chacon, J.; Palacios, J.; Gracia-Navarro, F.; Moreno-Bueno, G.; Malagon, M.M.; Luque, R.M.; et al. The new truncated somatostatin receptor variant sst5TMD4 is associated to poor prognosis in breast cancer and increases malignancy in MCF-7 cells. Oncogene 2011, doi:10.1038/onc.2011.389.

205. Bootsma, A.H.; van Eijck, C.; Schouten, K.K.; Reubi, J.C.; Waser, B.; Foekens, J.A.; van Pel, R.; Zwarthoff, E.C.; Lamberts, S.W.; de Klein, A. Somatostatin receptor-positive primary breast tumors: Genetic, patient and tumor characteristics. Int. J. Cancer 1993, 54, 357-362.

206. Fekete, M.; Wittliff, J.L.; Schally, A.V. Characteristics and distribution of receptors for [d-trp6]-luteinizing hormone-releasing hormone, somatostatin, epidermal growth factor, and sex steroids in 500 biopsy samples of human breast cancer. J. Clin. Lab. Anal. 1989, 3, 137-147.

207. Prevost, G.; Hosford, D.; Thomas, F. Receptors for somatostatin and somatostatin analogues in human breast tumors. Ann. NY Acad. Sci. 1994, 733, 147-154.

208. Prevost, G.; Lanson, M.; Thomas, F.; Veber, N.; Gonzalez, W.; Beaupain, R.; Starzec, A.; Bogden, A. Molecular heterogeneity of somatostatin analogue BIM-23014C receptors in human breast carcinoma cells using the chemical cross-linking assay. Cancer Res. 1992, 52, 843-850.

209. Prevost, G.; Provost, P.; Salle, V.; Lanson, M.; Thomas, F. A cross-linking assay allows the detection of receptors for the somatostatin analogue, lanreotide in human breast tumours. Eur. $J$. Cancer 1993, 29A, 1589-1592.

210. Foekens, J.A.; Portengen, H.; van Putten, W.L.; Trapman, A.M.; Reubi, J.C.; Alexieva-Figusch, J.; Klijn, J.G. Prognostic value of receptors for insulin-like growth factor 1, somatostatin, and epidermal growth factor in human breast cancer. Cancer Res. 1989, 49, 7002-7009.

211. Foekens, J.A.; van Putten, W.L.; Portengen, H.; Rodenburg, C.J.; Reubi, J.C.; Berns, P.M.; Henzen-Logmans, S.C.; van der Burg, M.E.; Alexieva-Figusch, J.; Klijn, J.G. Prognostic value of ps2 protein and receptors for epidermal growth factor (EGF-R), insulin-like growth factor-1 (IGF-1-R) and somatostatin (SS-R) in patients with breast and ovarian cancer. J. Steroid. Biochem. Mol. Biol. 1990, 37, 815-821.

212. Kumar, U.; Grigorakis, S.I.; Watt, H.L.; Sasi, R.; Snell, L.; Watson, P.; Chaudhari, S. Somatostatin receptors in primary human breast cancer: Quantitative analysis of mRNA for subtypes $1-5$ and correlation with receptor protein expression and tumor pathology. Breast Cancer Res. Treat. 2005, 92, 175-186.

213. Nelson, J.; Cremin, M.; Murphy, R.F. Synthesis of somatostatin by breast cancer cells and their inhibition by exogenous somatostatin and sandostatin. Br. J. Cancer 1989, 59, 739-742. 
214. Pagliacci, M.C.; Tognellini, R.; Grignani, F.; Nicoletti, I. Inhibition of human breast cancer cell (MCF-7) growth in vitro by the somatostatin analog SMS 201-995: Effects on cell cycle parameters and apoptotic cell death. Endocrinology 1991, 129, 2555-2562.

215. Prevost, G.; Foehrle, E.; Thomas, F.; Pihan, I.; Veber, N.; Starzec, A.; Israel, L. Growth of human breast cancer cell lines is inhibited by the somatostatin analog Bim23014. Endocrinology 1991, 129, 323-329.

216. Setyono-Han, B.; Henkelman, M.S.; Foekens, J.A.; Klijn, G.M. Direct inhibitory effects of somatostatin (analogues) on the growth of human breast cancer cells. Cancer Res. 1987, 47, 1566-1570.

217. Weber, C.; Merriam, L.; Koschitzky, T.; Karp, F.; Benson, M.; Forde, K.; LoGerfo, P. Inhibition of growth of human breast carcinomas in vivo by somatostatin analog SMS 201-995: Treatment of nude mouse xenografts. Surgery 1989, 106, 416-422.

218. Weckbecker, G.; Liu, R.; Tolcsvai, L.; Bruns, C. Antiproliferative effects of the somatostatin analogue octreotide (SMS 201-995) on Zr-75-1 human breast cancer cells in vivo and in vitro. Cancer Res. 1992, 52, 4973-4978.

219. Weckbecker, G.; Tolcsvai, L.; Liu, R.; Bruns, C. Preclinical studies on the anticancer activity of the somatostatin analogue octreotide (SMS 201-995). Metabolism 1992, 41, 99-103.

220. Weckbecker, G.; Tolcsvai, L.; Stolz, B.; Pollak, M.; Bruns, C. Somatostatin analogue octreotide enhances the antineoplastic effects of tamoxifen and ovariectomy on 7,12-dimethylbenz(alpha) anthracene-induced rat mammary carcinomas. Cancer Res. 1994, 54, 6334-6337.

221. van op den Bosch, J.; Torfs, P.; de Winter, B.Y.; de Man, J.G.; Pelckmans, P.A.; van Marck, E.; Grundy, D.; van Nassauw, L.; Timmermans, J.P. Effect of genetic SSTR4 ablation on inflammatory peptide and receptor expression in the non-inflamed and inflamed murine intestine. J. Cell. Mol. Med. 2009, 13, 3283-3295.

222. van op den Bosch, J.; van Nassauw, L.; Lantermann, K.; van Marck, E.; Timmermans, J.P. Effect of intestinal inflammation on the cell-specific expression of somatostatin receptor subtypes in the murine ileum. Neurogastroenterol. Motil. 2007, 19, 596-606.

223. Betoin, F.; Ardid, D.; Herbet, A.; Aumaitre, O.; Kemeny, J.L.; Duchene-Marullaz, P.; Lavarenne, J.; Eschalier, A. Evidence for a central long-lasting antinociceptive effect of vapreotide, an analog of somatostatin, involving an opioidergic mechanism. J. Pharmacol. Exp. Ther. 1994, 269, 7-14.

224. Tashev, R.; Belcheva, S.; Milenov, K.; Belcheva, I. Antinociceptive effect of somatostatin microinjected into caudate putamen. Peptides 2001, 22, 1079-1083.

225. Bell, J.R.; Young, M.R.; Masterman, S.C.; Morris, A.; Mattick, R.P.; Bammer, G. A pilot study of naltrexone-accelerated detoxification in opioid dependence. Med. J. Aust. 1999, 171, 26-30.

226. Maurer, R.; Gaehwiler, B.H.; Buescher, H.H.; Hill, R.C.; Roemer, D. Opiate antagonistic properties of an octapeptide somatostatin analog. Proc. Natl. Acad. Sci. USA 1982, 79, 4815-4817.

227. Mihm, M.J.; Amann, D.M.; Schanbacher, B.L.; Altschuld, R.A.; Bauer, J.A.; Hoyt, K.R. Cardiac dysfunction in the R6/2 mouse model of huntington's disease. Neurobiol. Dis. 2007, 25, 297-308.

228. Colao, A.; Marzullo, P.; di Somma, C.; Lombardi, G. Growth hormone and the heart. Clin. Endocrinol. (Oxf.) 2001, 54, 137-154.

229. Niehoff, D.L.; Mudge, A.W. Somatostatin alters beta-adrenergic receptor-effector coupling in cultured rat astrocytes. EMBO J. 1985, 4, 317-321. 
230. Mayor, F., Jr.; Benovic, J.L.; Caron, M.G.; Lefkowitz, R.J. Somatostatin induces translocation of the beta-adrenergic receptor kinase and desensitizes somatostatin receptors in S49 lymphoma cells. J. Biol. Chem. 1987, 262, 6468-6471.

231. Somvanshi, R.K.; Qiu, X.; Kumar, U. Isoproterenol induced hypertrophy and associated signaling pathways are modulated by somatostatin in H9c2 cells. Int. J. Cardiol. 2012, in press.

(C) 2012 by the authors; licensee MDPI, Basel, Switzerland. This article is an open access article distributed under the terms and conditions of the Creative Commons Attribution license (http://creativecommons.org/licenses/by/3.0/). 